\title{
Conflitos fundiários urbanos e a ocupação "Pinheirinho": acesso à moradia e remoção forçada
}

\author{
Urban conflicts and the 'Pinheirinho' occupation - access to housing and \\ forced removal
}

Isabel Cristina Nunes de Sousa[a] (1) , Carolina Maria Pozzi de Castro [a,b] []

[a] Universidade Federal de São Carlos (UFSCar), São Carlos, SP, Brasil

[b] Universidade Federal do ABC (UFABC), Santo André, SP, Brasil

Como citar: Sousa, I. C. N. \& Castro, C. M. P. (2019). Conflitos fundiários urbanos e a ocupação "Pinheirinho": acesso à moradia e remoção forçada. urbe. Revista Brasileira de Gestão Urbana, 11, e20170157. https://doi.org/10.1590/21753369.011.e20170157

\section{Resumo}

Aprofundando a discussão acerca dos direitos à cidade, especificamente o direito à moradia adequada, neste estudo é retratado um emblemático exemplo de conflito fundiário urbano, representado pela ocupação de terreno ocioso. Empregou-se o método qualitativo, compondo uma pesquisa exploratória e descritiva da problemática abordada. Descreve-se a destinação conferida a uma área conhecida popularmente como "Pinheirinho", gleba localizada na região sul da cidade de São José dos Campos/SP, a qual permaneceu inutilizada por 30 anos, até ser ocupada por 1.789 famílias em 2004. São apresentadas as repercussões concernentes à segregação socioespacial após o processo de reintegração de posse da área, ocorrido em 2012, além da demonstração da resiliência dos ocupantes em permanecer no local, com um histórico dos acontecimentos e da trajetória dos moradores. Indiferente ao fato de consolidada a ocupação em um terreno em descumprimento à função social da propriedade, com dívidas perante o poder público municipal, os interesses individuais de propriedade foram resguardados em detrimento do bem-estar da coletividade no processo de desocupação do Pinheirinho, de tal maneira que a ocupação irregular por parte de uma população em situação de vulnerabilidade social foi tolerada por 8 anos.

Palavras-chave: Função social. Direito à cidade. Moradia adequada.

\section{Abstract}

Deepening the discussion about the right to the city, specifically the right to adequate housing, in this study, an emblematic example of an urban land conflict is presented, represented by the occupation of an idle parcel of urban land. By using the qualitative method, an exploratory and descriptive research of the problematic approached was composed. We describe the destination of an area popularly known as 'Pinheirinho', a parcel of land located southbound of São José dos Campos city, which remained abandoned for 30 years, until it had been occupied by 1.789 families in 2004. We present the repercussions concerning the socio-spatial segregation after the repossession process in 2012, and demonstrate the occupants

ICNS é gestora e analista ambiental, com mestrado em Engenharia Urbana pela Universidade Federal de São Carlos (PPGEU/UFSCar), e-mail: sousa.isabelnunes@gmail.com

CMPC é arquiteta e urbanista e professora da Universidade Federal do ABC (UFABC), e-mail: ccastro@ufscar.br 
resilience in staying. Indifferent to the fact that this was a consolidated occupation, inside a piece of land that failed performing its social function of propriety, and has been in fiscal debt with the municipal government, individual interests were safeguarded in the Pinheirinho eviction process, to the detriment of community welfare. In such a way, the illegal occupation by a socially vulnerable population was tolerated for 8 years.

Keywords: Social role. Right to the city. Appropriate housing.

\section{Introdução}

A despeito dos recentes avanços na política urbana, trazidos por um arcabouço jurídico consistente, com diversos marcos legais e normativos referenciais ${ }^{1}$ (Fernandes, 2003; Saule \& Di Sarno, 2013; Teixeira \& Silva, 2016), as desigualdades socioespaciais das cidades brasileiras se mantêm.

Trata-se de uma realidade atrelada à concentração de terras e à inoperância na aplicação de políticas públicas de democratização do solo urbanizado (Frota, 2015), evidenciada pela paradoxal retenção especulativa do solo urbano (existência de vazios urbanos e prédios ociosos cercados por infraestrutura consolidada), em contraposição a déficits habitacionais e precárias condições de moradia (Fernandes, 2008).

Aprofundando a discussão acerca dos direitos à cidade ${ }^{2}$, especificamente o direito à moradia adequada, retrata-se neste estudo um emblemático exemplo de conflito fundiário urbano, representado pela ocupação de terreno ocioso.

Descreve-se a destinação conferida a uma área conhecida como "Pinheirinho", gleba localizada na região sul da cidade de São José dos Campos/SP (SJC/SP), a qual permaneceu inutilizada por 30 anos, até ser ocupada por 1.789 famílias em 2004. São apresentadas as repercussões concernentes à segregação socioespacial após o processo de reintegração de posse da área em 2012, além de um breve histórico dos acontecimentos e da trajetória dos moradores.

Empregou-se o método qualitativo, compondo uma pesquisa exploratória e descritiva da problemática abordada. Os seguintes procedimentos metodológicos foram adotados: a) averiguação da atuação judicial para promoção da tutela dos interesses coletivos; b) apuração das formas de assistência jurídica prestadas; c) levantamento de possíveis débitos fiscais referentes a tributos municipais da gleba; d) verificação de informações sobre a construção dos conjuntos habitacionais para os quais os antigos ocupantes do Pinheirinho foram realocados; d) espacialização e delimitação georreferenciada da área de estudo.

Dados primários foram coletados em órgãos, como o Ministério Público Federal e a Defensoria Pública - instituições capazes de garantir o acesso à justiça e o alcance da tutela jurisdicional de direitos fundamentais para populações carentes (Teixeira \& Silva, 2016) -, além das Secretarias Municipais da Fazenda e de Habitação de SJC/SP.

\section{Inserção da Ocupação Pinheirinho no território Joseense}

Localizado na região sudeste do Estado de São Paulo, a cerca de $90 \mathrm{~km}$ da capital, SJC/SP integra a Região Metropolitana do Vale do Paraíba e do Litoral Norte (São Paulo, 2012). No Quadro 1, apresentase um panorama do recorte empírico para detalhamento da configuração socioeconômica do município.

A cidade situa-se entre duas regiões metropolitanas, São Paulo e Rio de Janeiro (Forlin \& Costa, 2010), sendo um reconhecido polo industrial, científico, tecnológico e de serviços devido à presença de empresas de alta tecnologia e de várias indústrias ${ }^{3}$, além de possuir um desenvolvido setor aeroespacial (Forlin \& Costa, 2010; PMSJC, 2015).

1 Principalmente o capítulo sobre política urbana da Constituição Federal de 1988, introduzido pelos artigos 182 e 183, que, posteriormente, foram regulamentados pelo Estatuto da Cidade (Lei Federal no 10.257/2001).

2 Termo cunhado, inicialmente, pelo filósofo e sociólogo francês Henri Lefebvre, em seu livro "Le Droit à la ville", publicado em 1968.

3 "Com intuito de atrair investimentos industriais para a cidade, a lei municipal no 4, de 13 de maio de 1920, concedia isenção de impostos por um período de 25 anos e terreno gratuito" (PMSJC, 2011, p. 10). 
Quadro 1 - Caracterização socioeconômica do município

\begin{tabular}{|c|c|}
\hline População total (habitantes) & 703.219 \\
\hline Densidade demográfica (hab./km²) & 572,96 \\
\hline Grau de urbanização (\%) & 97,97 \\
\hline Índice de Desenvolvimento Humano Municipal (IDHM) & 0.807 \\
\hline Aglomerados subnormais (domicílios particulares) & 2.015 \\
\hline População residente em aglomerados subnormais & 7.310 \\
\hline Domicílios em assentamentos precários & 5.820 \\
\hline Estimativa de pessoas em assentamentos precários & 20.988 \\
\hline População em domicílios com água encanada (\%) & 98,84 \\
\hline População em domicílios com energia elétrica (\%) & 99,95 \\
\hline População em domicílios com coleta de lixo (\%) & 99,82 \\
\hline População em domicílios com banheiro e água encanada (\%) & 97,34 \\
\hline Esgotamento sanitário adequado (\%) & 94,30 \\
\hline PIB per capita (R\$) & $52.858,35$ \\
\hline Renda per capita (R\$) & $1.190,96$ \\
\hline Índice de Gini (grau de concentração de renda) & 0,53 \\
\hline Salário médio mensal dos trabalhadores formais em salários mínimos (s.m.) & 4,0 \\
\hline Popupão com rendimento nominal mensal per capita de até meio salário mínimo (\%) & 32,30 \\
\hline & 33,40 \\
\hline & 54,82 \\
\hline
\end{tabular}

Fonte: ATLAS BRASIL (2018); CEM \& Cebrap (2013a, b); EMPLASA (2018); SEADE (2018); IBGE (2018).

É possível perceber, no entanto, que o município espelha as contradições de um "modelo de crescimento implantado no País [que] alijou a imensa maioria dos benefícios de uma sociedade que teve notável desempenho econômico" (Kowarick, 2000, p. 20), de tal forma que se constata a permanência de loteamentos periféricos clandestinos e/ou irregulares (aglomerações subnormais), sem acesso a serviços e infraestrutura básicos, simultaneamente à manutenção de áreas desocupadas, providas de infraestrutura e dentro do perímetro urbano, à espera de futura valorização (Freitas \& Costa, 2005).

É uma conjuntura que se acentuou com a consolidação econômica baseada em indústrias, tornando SJC/SP alvo de intensa migração em busca de trabalho, principalmente na época de acelerada urbanização (década de 1970), algo que, combinado à "fraca política habitacional para a população de baixa renda" (PMSJC, 2016a, p. 55), resultou na demanda por moradias e consequente elevação no valor da terra urbanizada, dificultando o acesso ao mercado formal de habitação e colaborando para formação de núcleos de favelas e expansão de loteamentos irregulares (Suriano, 2013).

\section{Políticas habitacionais e diretrizes de uso e ocupação do solo}

De acordo com Forlin \& Costa (2010), até 1970 não existiam políticas públicas municipais referentes ao setor de habitação popular em SJC/SP. E, quando tais políticas começam a ser aplicadas, transformam-se em instrumentos de segregação socioespacial, com atendimento a determinados grupos sociais e marginalização dos estratos de menor renda, havendo predileção por alocar a população carente em zonas extremamente afastadas e sem infraestrutura instalada (Forlin \& Costa, 2010).

Trata-se de uma situação reforçada pela política habitacional adotada durante todo o período da ocupação, sob três gestões do Partido da Social Democracia Brasileira (PSDB) (2001-2004, 2005-2008 e 2009-2012), em que as diretrizes e as principais ações se concentraram, predominantemente, na 
remoção de favelas e na realocação populacional em conjuntos habitacionais construídos em parceria com o governo estadual ou federal.

A oferta de unidades habitacionais ocorreu em regiões majoritariamente periféricas e sem infraestrutura (Suriano, 2013). Nesse recorrente modelo de provisão habitacional, a inclusão social plena não ocorre, e a propagação da informalidade e a dificuldade de inserção no mercado de trabalho são comuns, visto o distanciamento dos locais de oferta de emprego.

Conforme estipulado pela Lei Federal no 11.124 (Brasil, 2005), no ano de 2009 foi criado o Fundo Municipal de Habitação em SJC/SP, com o Plano Local de Habitação de Interesse Social (PLHIS) sendo entregue em 2012. Ironicamente, o PLHIS reconhece que "a produção de habitação de interesse social (HIS) não deve se restringir às localizações distantes e com pouca infraestrutura, num sentido de promover uma distribuição mais igualitária de acessos e oportunidades" (PMSJC, 2011, p. 36).

0 primeiro objetivo definido para o PLHIS era a criação de "mecanismos para buscar atender e controlar o déficit habitacional do município" (PMSJC, 2011, p. 40), que era da ordem de 2.560 residências no ano de 2004 (PMSJC, 2006, p. 52), tendo evoluído para 7.440 domicílios em 2010 (PMSJC, 2011, p. 30).

Esse déficit se contrapõe à existência de diversos vazios urbanos na localidade, como apontado no próprio PLHIS: "no universo dos vazios analisados, a soma das áreas aptas a receber empreendimentos habitacionais em São José dos Campos resulta em um total de 54.923.085,34 m²" (PMSJC, 2011, p. 36).

Ainda assim, desde a década de 1980, previam-se diretrizes para os vazios urbanos nas leis de zoneamento do município. A Lei no 2.263, aprovada em 1980 (São José dos Campos, 1980), por exemplo, determinou a diminuição do perímetro urbano para incentivar a ocupação dos vazios urbanos. No entanto, para Reani (2016), essa diretriz ocasionou o acréscimo de loteamentos clandestinos, ocupando áreas destinadas ao uso industrial, ambientalmente protegidas e vulneráveis do município, como encostas de morros e margens de corpos hídricos, tanto que, no período de vigência da mencionada lei, "foram promulgadas 21 leis municipais que dispunham sobre a regularização dos loteamentos clandestinos, sem contar os decretos" (Reani, 2016, p. 199).

Na década seguinte, a lei de zoneamento foi substituída pela Lei no 3.721/1990 (São José dos Campos, 1990), criando a Zona de Vazio Urbano (ZVU), definida no inciso XXVIII do art. 88 como "zona de uso compreendida por glebas de médio e grande porte, não ocupadas, constituindo vazios no perímetro urbano, necessitando de planejamento específico para sua ocupação" (São José dos Campos, 1990). A problemática dos loteamentos clandestinos se acentuou na época, tendo havido "mais de quinze Leis Complementares na década de 1990 que visavam a regulação de loteamentos clandestinos" (Reani, 2016, p. 201-202).

Com a lei de zoneamento urbano de 1997 - Lei no 165 (São José dos Campos, 1997) -, a ZVU se manteve. No entanto, "não são colocadas medidas efetivas para a ocupação dessas áreas. [...] na prática pouco é feito para ocupação dessas áreas, o que acaba levando à expansão da área urbana sobre a área rural e [de] proteção ambiental" (Reani, 2016, p. 203).

Segundo Reani (2016, p. 208), "na lei no 165/97, os loteamentos clandestinos ocupavam uma área de $14,54 \mathrm{~km}^{2}$, em 2010 esta área aumenta para $20,38 \mathrm{~km}^{2}$, representando um crescimento de $40 \%$ na área ocupada por loteamentos clandestinos". E a área destinada à ZVU era de 70,38 km² em 1990, tendo caído para 48,95 km² em 1997 e chegado a 101,42 km² em 2010 (Reani, 2016, p. 213-214). Conforme Freitas \& Costa (2005), no ano de 2000, os vazios intraurbanos de SJC/SP superiores a $5 \mathrm{mil} \mathrm{m}^{2}$ somavam $6,147 \mathrm{~km}^{2}$, o equivalente a 2,08\% da área total da Macrozona Urbana, que possui, aproximadamente, $297 \mathrm{~km}^{2}$ - a área total do município é de 1.099,409 km² (IBGE, 2018).

Dos terrenos ociosos existentes na cidade, destaca-se na Figura 1 a área referente ao estudo de caso, situada na Estrada do Imperador, no bairro Jardim Colonial, região sul ${ }^{4}$ da cidade (setor censitário 12).

\footnotetext{
4 Região geográfica com área total de 56,51 km² (PMSJC, 2016a), sendo a mais populosa do município, com 233.536 habitantes e $40 \%$ da população urbana (PMSJC, 2006).
} 


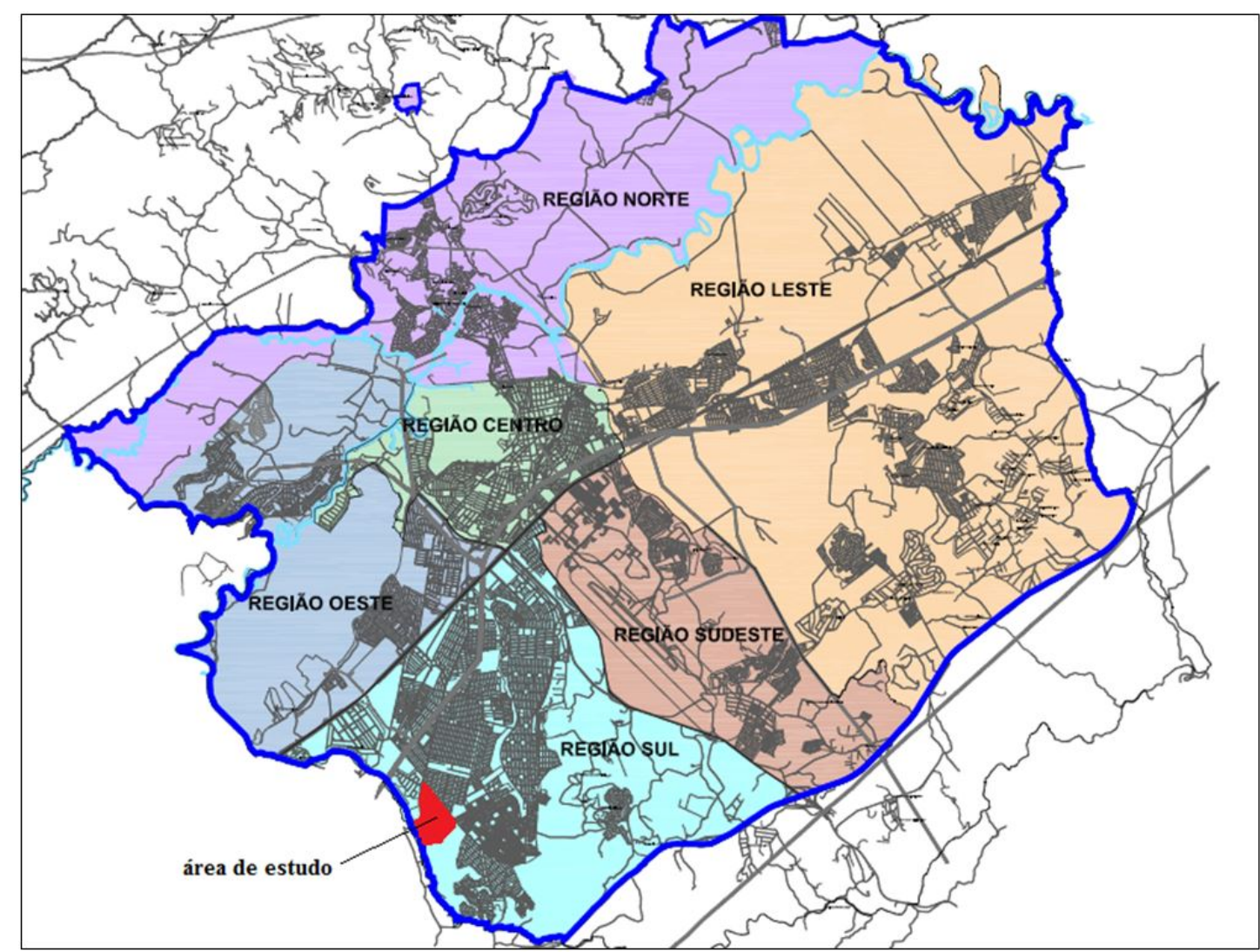

Figura 1 - Localização da área de estudo na cidade. Fonte: adaptada do Mapa 2 - Regiões Geográficas, Lei Complementar n 428/10 (São José dos Campos, 2010).

A existência de espaços ociosos, conflitos fundiários e segregação socioespacial na região sul foram constatados por Andrade (2010), ao relatar que, embora seja uma das regiões que mais propiciou a ocupação organizada da cidade (em áreas visadas para as classes médias e para a construção de conjuntos habitacionais), esta passou também por um processo de concentração de extensos vazios urbanos, grandes ocupações de terras em áreas afastadas e constantes conflitos por regularização fundiária.

O vazio urbano abordado (Figura 2) consiste em uma gleba de $1.379 .200,00 \mathrm{~m}^{2}$ (PMSJC, 2017) e, assim como 29,1\% das áreas de vazios urbanos identificadas em 2010 (Reani, 2016), situa-se em Zona Industrial (ZI) com boa inserção urbana, acesso à infraestrutura, com comércios e serviços - coordenadas

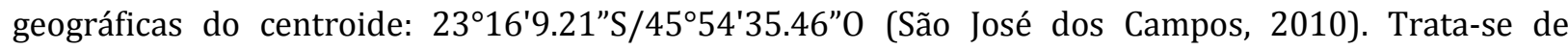
propriedade da massa falida ${ }^{5}$ da empresa Selecta Comércio e Indústria S.A., holding ${ }^{6}$ que englobava 27 empresas pertencentes a Naji Nahas ${ }^{7}$ (Montenegro, 2013).

5 Em 14 de junho de 1989, iniciou-se processo de recuperação judicial e falência da Selecta (São Paulo, 2016).

6 Empresa gestora de participações sociais, que detém a maioria acionária de uma ou mais empresas e é responsável por geri-las (Pires \& Souza, 2014, p. 109).

7 Investidor libanês que veio ao Brasil na década de 1960, tendo adquirido o terreno do Pinheirinho em 1981 (Crespo, 2013 ). Proprietário da Selecta S.A., o empresário foi investigado em 2008 pela Polícia Federal durante a Operação Satiagraha - Inquérito Policial Federal no 2007.61.81.0001285. Nessa operação, comandada pelo então delegado de Polícia Federal Protógenes Queiroz, Nahas foi investigado pelos crimes de gestão fraudulenta, lavagem de dinheiro público desviado, evasão de divisas e uso de informação privilegiada (Pires \& Souza, 2014). Em 2011, a Operação Satiagraha foi anulada pelo Superior Tribunal de Justiça (STJ), em função de ilegalidades na condução da coleta de provas (Macedo \& Affonso, 2015). 


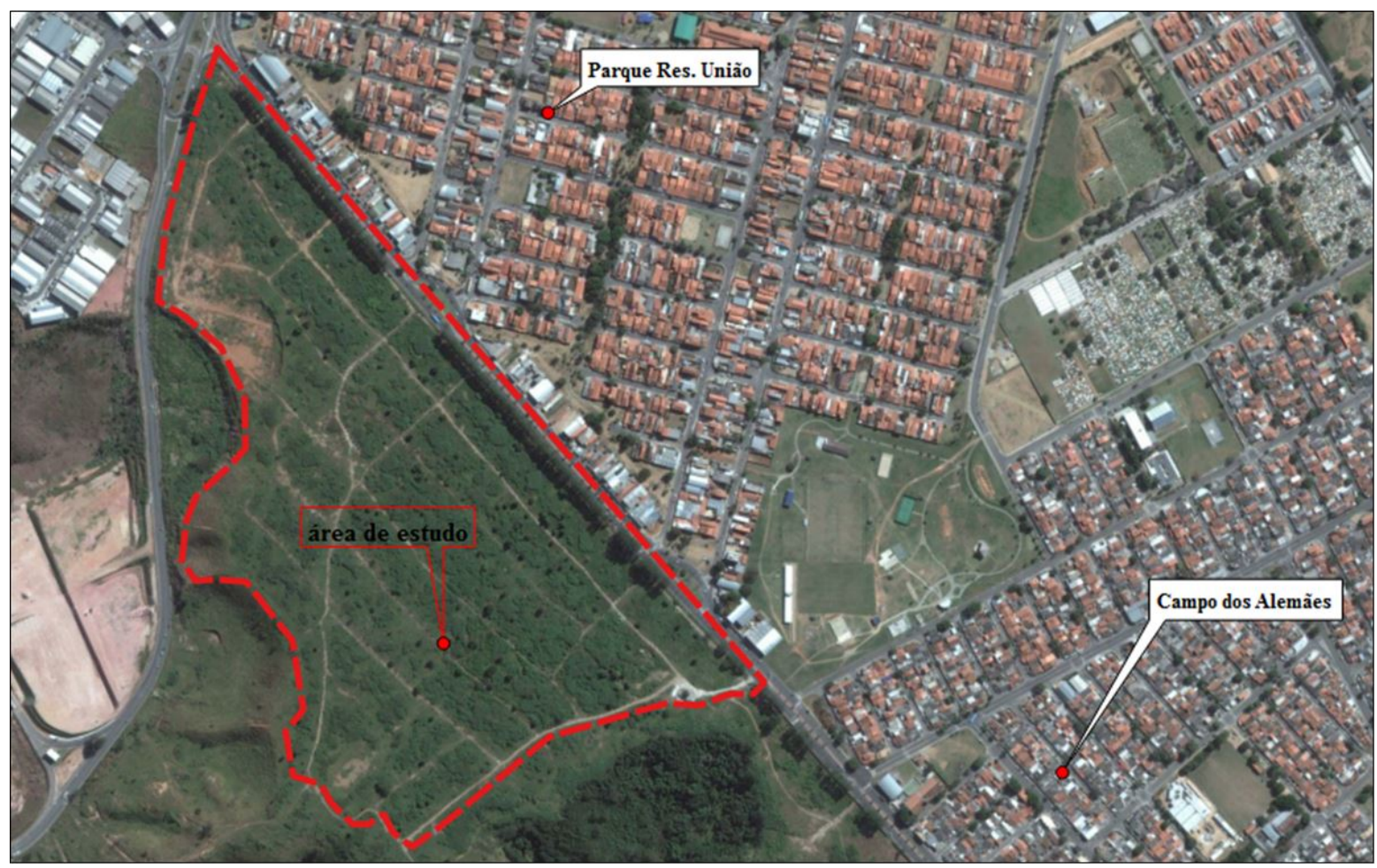

Figura 2 - Delimitação da área de estudo e bairros adjacentes. Fonte: elaboração própria.

Conforme consulta ao sistema de emissão da Certidão de Dados Cadastrais Imobiliários da Prefeitura Municipal de SJC/SP, realizada em 21 de abril de 2017, o terreno estava avaliado em R \$134.568.544,00 (PMSJC, 2017) e acumulava, em 18 de fevereiro de 2016, uma dívida de IPTU com a Prefeitura Municipal no valor de R \$ 91.730.051,78 (PMSJC, 2016b). A inadimplência no pagamento desse imposto iniciou-se em 1991, dois anos após a declaração de falência da empresa proprietária do terreno (PMSJC, 2016c).

No dia 29 de novembro de 2016, a Prefeitura Municipal de SJC/SP ingressou em juízo com ação de cobrança da massa falida da Selecta Comércio e Indústria S.A. (JFSP, 2016). Iniciou-se, portanto, o

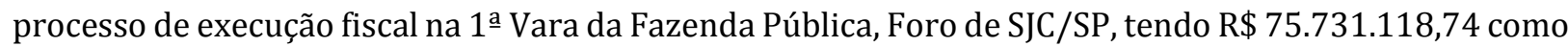
valor da ação de cobrança (TJSP, 2017).

\section{Trajetória dos moradores do Pinheirinho}

O vazio urbano ora tratado é conhecido na cidade como "Pinheirinho", em função dos pinheiros que contornam um dos lados de seus limites, e esteve abandonado por 30 anos (Suave, 2009; Andrade, 2010). Em 26 de fevereiro de 2004, ele foi ocupado por 1.789 famílias, com cerca de 6 mil pessoas (Souza, 2016).

A história dos ocupantes da área se iniciou com a ida de cerca de 100 famílias, após terem sido removidas de áreas públicas, para o terreno do Pinheirinho em 2004, um local definido por Antonio Ferreira, um dos advogados da associação de moradores do Pinheirinho, como "uma terra que estava perdida há muito tempo. [...] um terreno baldio, que servia apenas pra desova de cadáveres... Só servia pra isso, não tinha absolutamente nada nesse terreno" (Lespier et al., 2013).

A ocupação informal da área, que começou como "um acampamento [...] organizado pelo Movimento Urbano dos Sem Teto (MUST)", de acordo com Andrade (2010, p. 46), durou oito anos, período em que contou com o apoio institucional de centrais sindicais e partidos políticos ${ }^{8}$, como: Central Única dos

\footnotetext{
8 "A partir da interação mais ou menos intensa e continuada com atores do campo político-institucional os movimentos buscam o acesso ao poder político, de forma a produzir consequências no plano legislativo, nos processos de produção das políticas públicas, no controle sobre os aparatos administrativos etc." (Tatagiba, 2010, p. 69).
} 
Trabalhadores (CUT), Sindicato dos Metalúrgicos de SJC/SP (entidade controlada pela Conlutas), Movimento dos Trabalhadores Rurais Sem Terra (MST), Partido Socialista dos Trabalhadores Unificado (PSTU), Partido dos Trabalhadores (PT), Partido Comunista do Brasil (PCdoB), Partido Socialismo e Liberdade (PSOL) e Partido Verde (PV) (Andrade, 2010).

Com base em uma ordem do Superior Tribunal de Justiça do Estado de São Paulo, que reconheceu o "cabimento da execução de uma liminar de reintegração de posse quase oito anos após a propositura da ação" (Ginjo, 2016, p. 72), foi iniciada a reintegração de posse ${ }^{9}$ em 22 de janeiro de 2012.

A remoção das famílias do terreno do Pinheirinho foi realizada com auxílio da Guarda Municipal e de força policial composta por 2 mil policiais militares, preparados para tal finalidade, como é recorrente em eventos dessa natureza (Montenegro, 2013; MPF, 2012a). Na retirada dos ocupantes, houve confronto entre os moradores e a Polícia Militar (PM), com relatos de feridos e prisões efetuadas, além de violações dos direitos humanos no processo de desocupação da área, conforme denúncias enviadas à Comissão Interamericana de Direitos Humanos da Organização dos Estados Americanos (OEA) (Ginjo, 2014). Ademais, a desocupação não foi acompanhada pelos "advogados dos moradores, Defensoria Pública, Ordem dos Advogados do Brasil e demais instituições e autoridades [que] foram impedidos de entrar no Pinheirinho", conforme destacado por Ginjo (2016, p. 77).

Os registros fotográficos publicados pelos jornais The Guardian (2016) e BBC (2016), após repercussão internacional do caso, ilustram o processo de retirada forçada dos moradores, em que estes utilizaram armamento improvisado como forma de resistência, no intuito de atravancar as pretensões de remoção, e a PM utilizou balas de borracha e gás lacrimogênio.

A descrição fornecida por Rolnik et al. (2012) mostra como se deu a desastrosa e violenta desocupação, ocorrida às 6 horas da manhã de um domingo, com presença ostensiva de aparato policial de repressão:

Milhares de homens, mulheres, crianças e idosos moradores da ocupação Pinheirinho são surpreendidos por um cerco formado por helicópteros, carros blindados e mais de 1.800 homens armados da Polícia Militar. Além de terem sido interditadas as saídas da ocupação, foram cortados água, luz e telefone, e a ordem era que [as] famílias se recolhessem para dar início ao processo de retirada.

A resistência à desocupação deveu-se à suspensão da reintegração de posse, que se baseou, segundo o advogado Antonio Ferreira, em uma liminar da Justiça Federal. Conforme o mencionado advogado, somente pouco antes da chegada da Polícia Militar, na madrugada da desocupação, chegou a notícia de que a liminar "tinha caído", ou seja, havia sido suspensa ${ }^{10}$ (Lespier et al., 2013).

Montenegro (2013) registra que o terreno baldio ocupado pelas famílias do Pinheirinho passou por diversas transformações, "que o tornaram um bairro com ruas internas, quadras, 81 pontos comerciais, seis templos religiosos e duas praças".

Nas Figuras 3-6, retrata-se o processo de modificação do terreno, com a construção de moradias improvisadas e posterior demolição delas.

Muitas famílias procuraram igrejas e casa de familiares após a desocupação, além de terem sido encaminhadas para abrigos improvisados indicados pela Prefeitura Municipal, como ginásios e quadras poliesportivas (Machado, 2014).

\footnotetext{
Para maiores detalhes a respeito do andamento judicial do processo de reintegração de posse, consultar Ginjo (2016, p. 41-72).

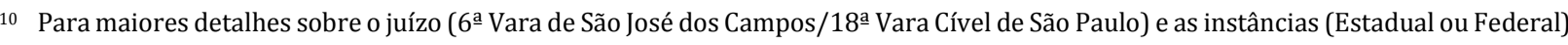
com competência sobre o caso, vide trabalho de Ginjo (2014).
} 


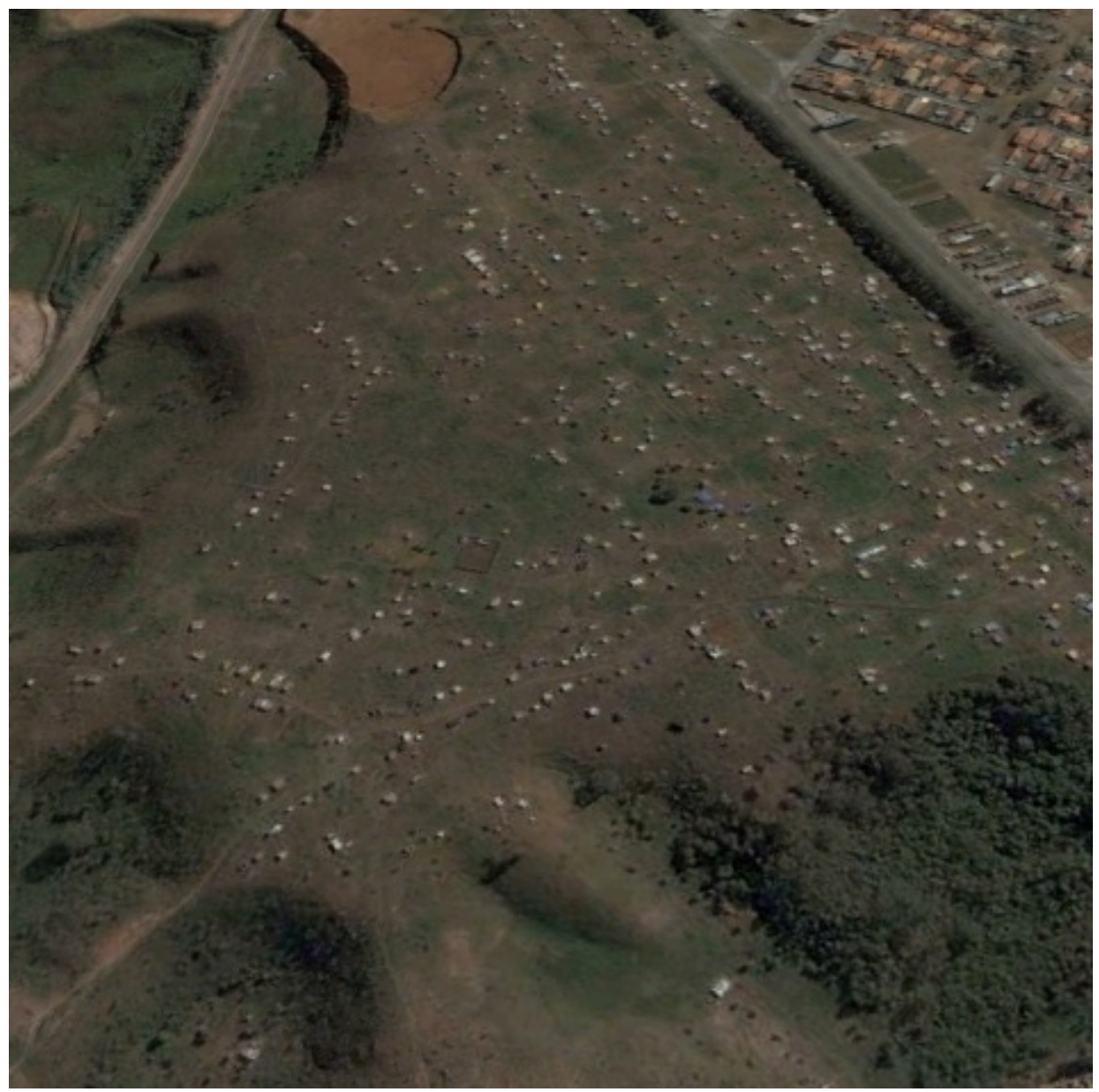

Figura 3 - Imagem aérea do Pinheirinho antes da ocupação (ano de 2004). Fonte: Google (2015).

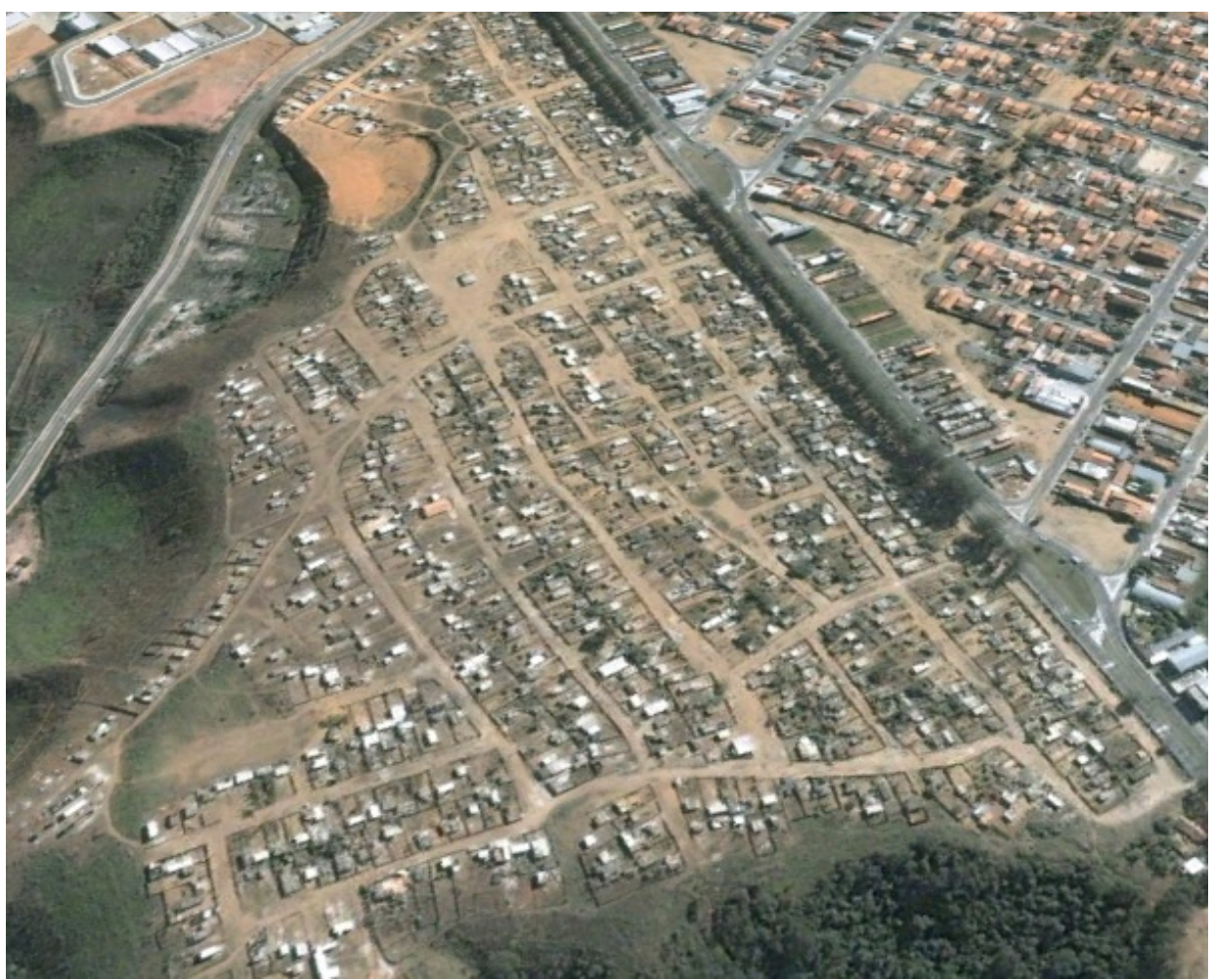

Figura 4 - Imagem aérea do Pinheirinho durante a ocupação (ano de 2008). Fonte: Google (2015). 


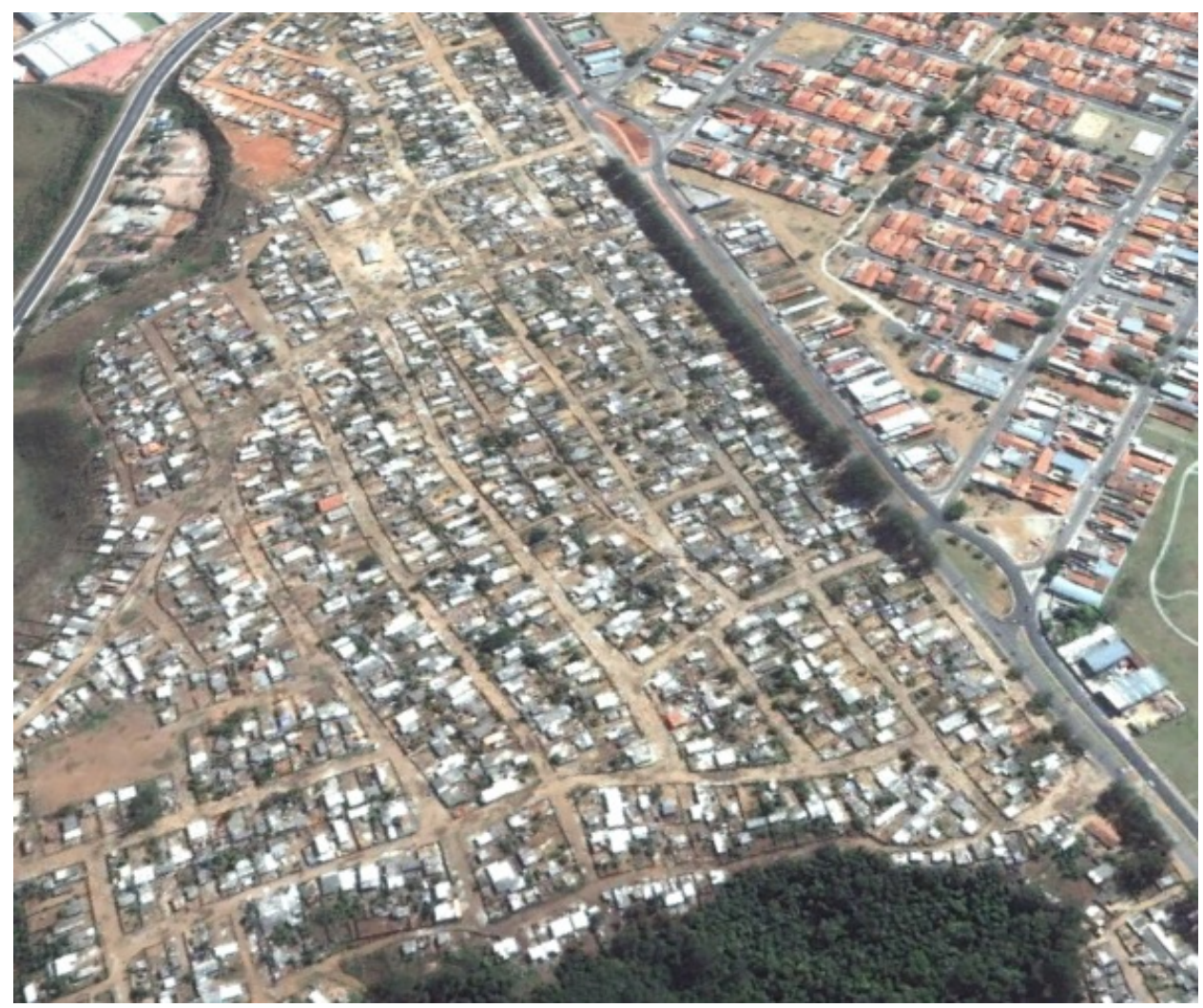

Figura 5 - Imagem aérea do Pinheirinho antes da desocupação (ano de 2012). Fonte: Google (2015).

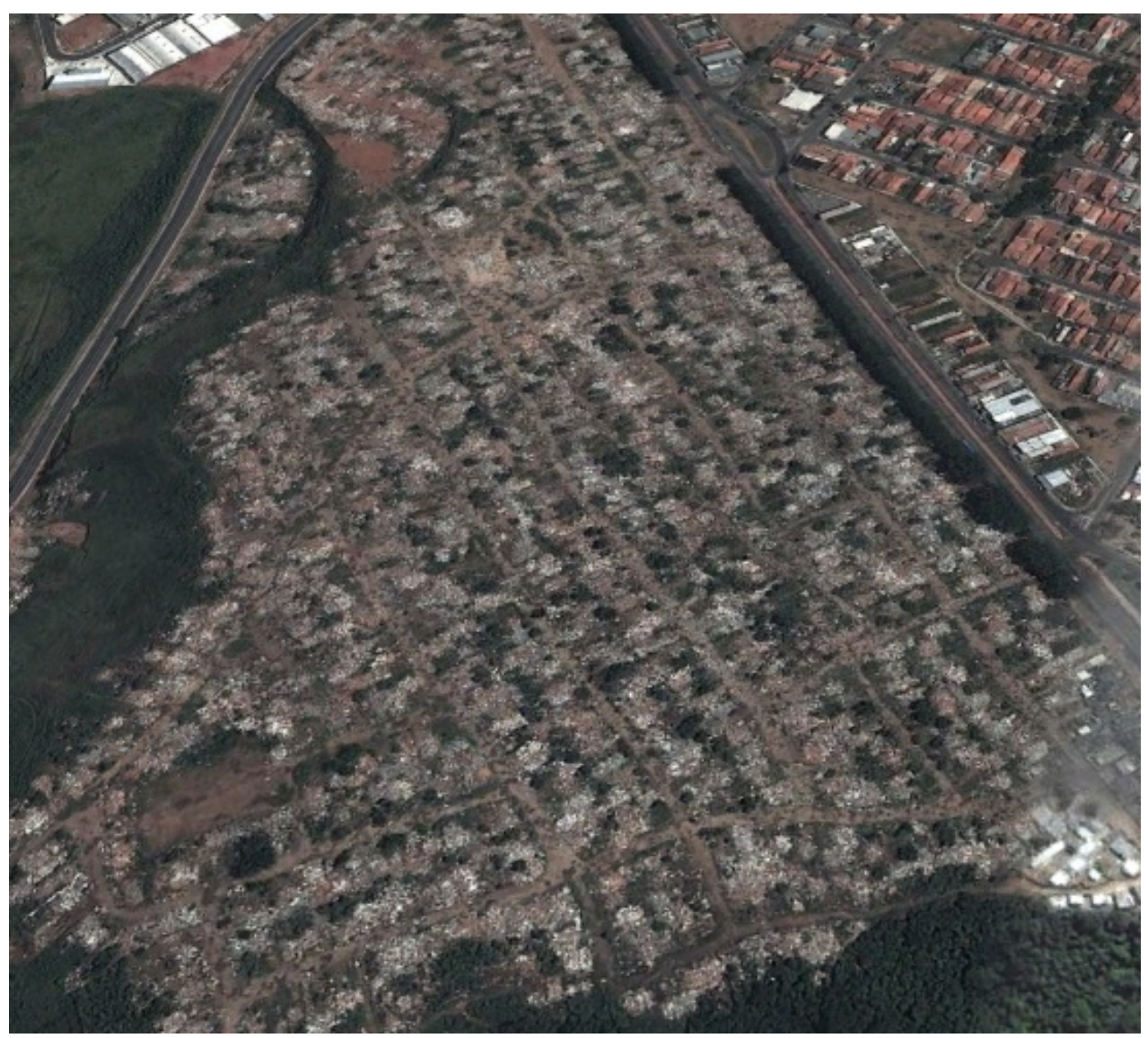

Figura 6 - Imagem aérea do Pinheirinho após desocupação e demolição das casas (ano de 2012). Fonte: Google (2015). 
Como medida paliativa, os antigos ocupantes do Pinheirinho receberam um valor assistencial de $\mathrm{R} \$ 500,00$ por mês de aluguel social ${ }^{11}$. Desse total, $\mathrm{R} \$ 400,00$ foram repassados pelo Governo do Estado de São Paulo e R \$100,00 reais eram recursos próprios do município de SJC/SP, para custeio das despesas de moradia (São José dos Campos, 2012).

Em dezembro de 2016, os ex-moradores do Pinheirinho foram realocados para os conjuntos habitacionais Pinheirinho dos Palmares12 I e II, loteamentos do Programa Minha Casa Minha Vida (PMCMV) com 239 e 1.461 unidades, respectivamente. Esses conjuntos situam-se no bairro do Putim (coordenadas geográficas do centroide: $23^{\circ} 14^{\prime} 58.68^{\prime \prime S} / 45^{\circ} 48^{\prime} 5.05^{\prime \prime} 0$ ), na zona sudeste da cidade, e estão "totalmente desarticulado[s] da malha urbana, próximo[s] à Rodovia Carvalho Pinto, a quase $20 \mathrm{~km}$ da Região Central" (Alvarenga \& Reschilian, 2018), a uma distância linear de, aproximadamente, $12 \mathrm{~km}$ da área desocupada.

Atualmente, persistem alguns barracos ao redor do Pinheirinho, que permanece desabitado, conforme fotos obtidas em 23 de abril de 2016 (Figuras 7-12).

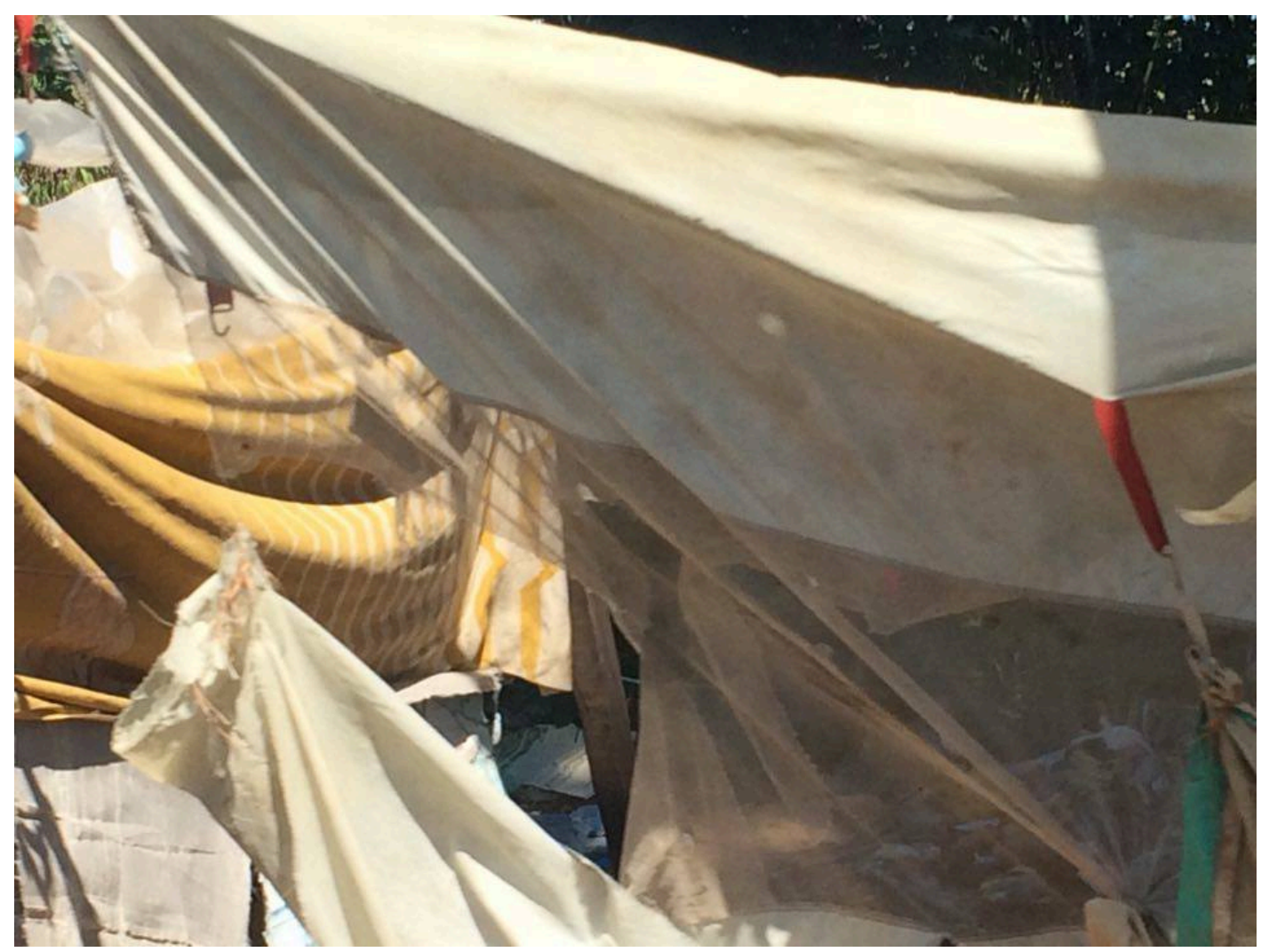

Figura 7 - Registro fotográfico do entorno do terreno do Pinheirinho. Fonte: acervo pessoal (2016).

\footnotetext{
11 Como consequência dessa iniciativa, tem-se o aumento imediato do valor de locação de imóveis populares na cidade, tornando-se extremamente difícil alugar uma casa adequada somente com o valor pago (Rolnik, 2012b).

12 Em alusão a Zumbi dos Palmares, líder do Quilombo dos Palmares.
} 


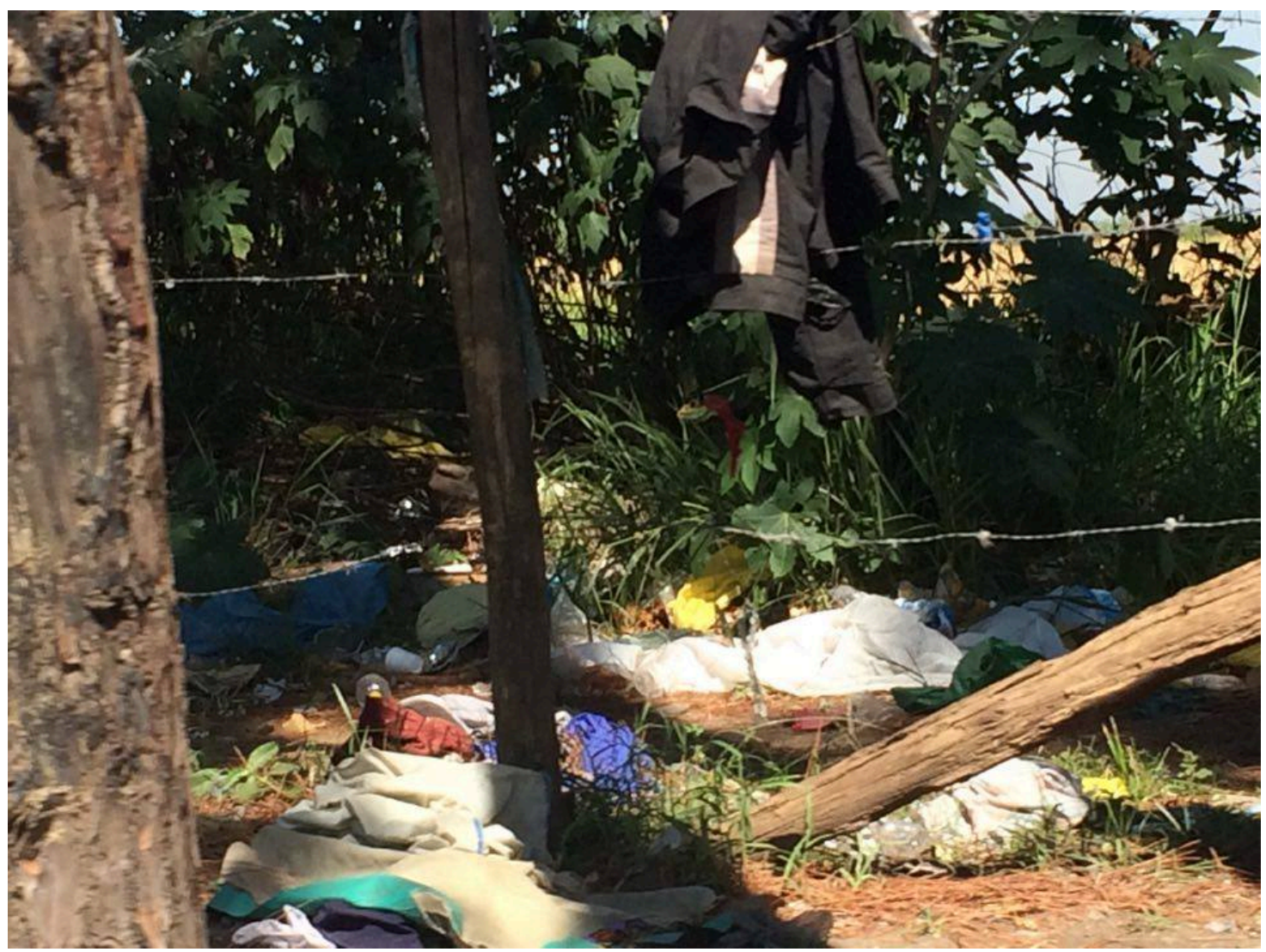

Figura 8 - Registro fotográfico do entorno do terreno do Pinheirinho. Fonte: acervo pessoal (2016).
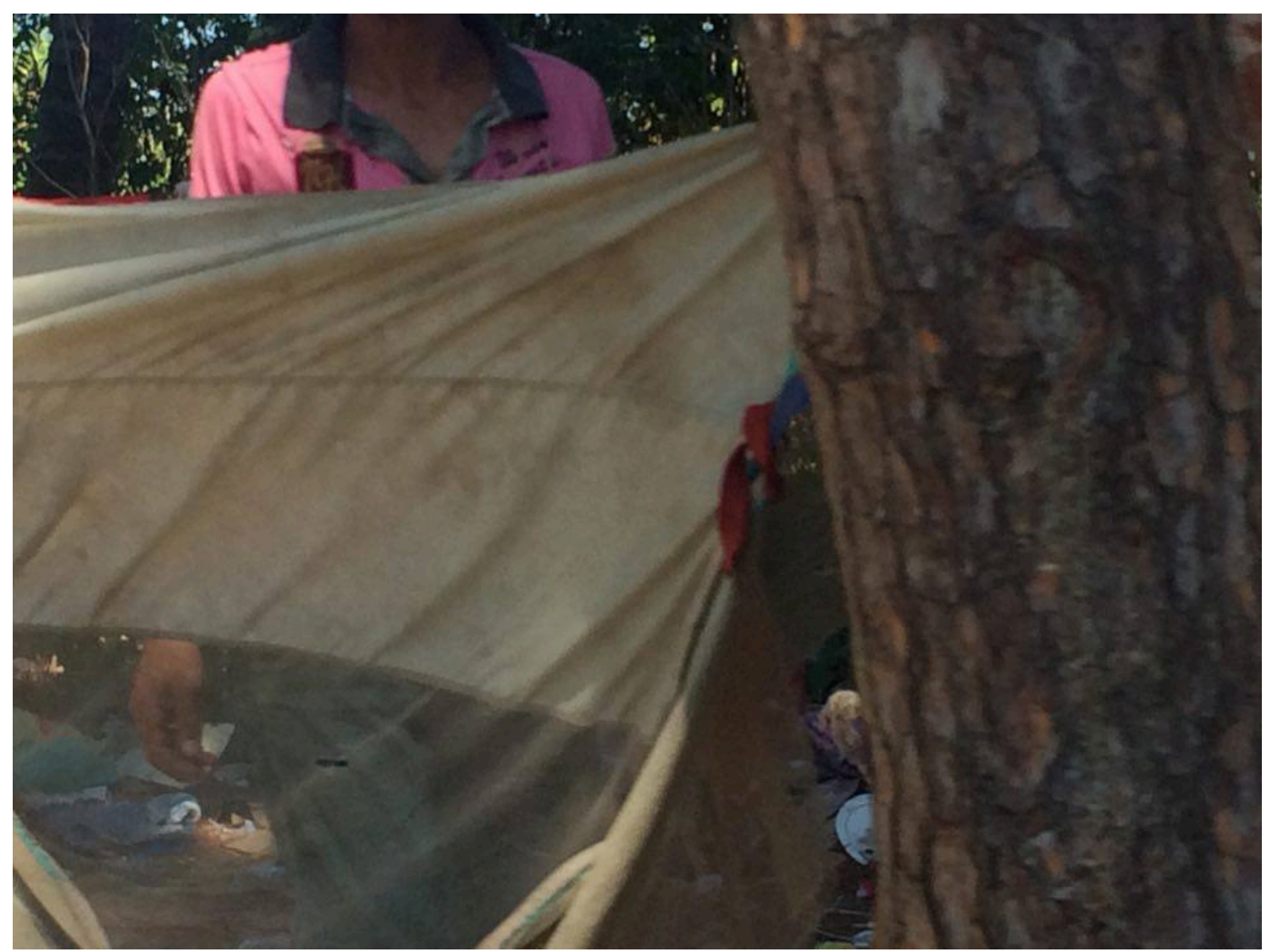

Figura 9 - Registro fotográfico do entorno do terreno do Pinheirinho. Fonte: acervo pessoal (2016). 


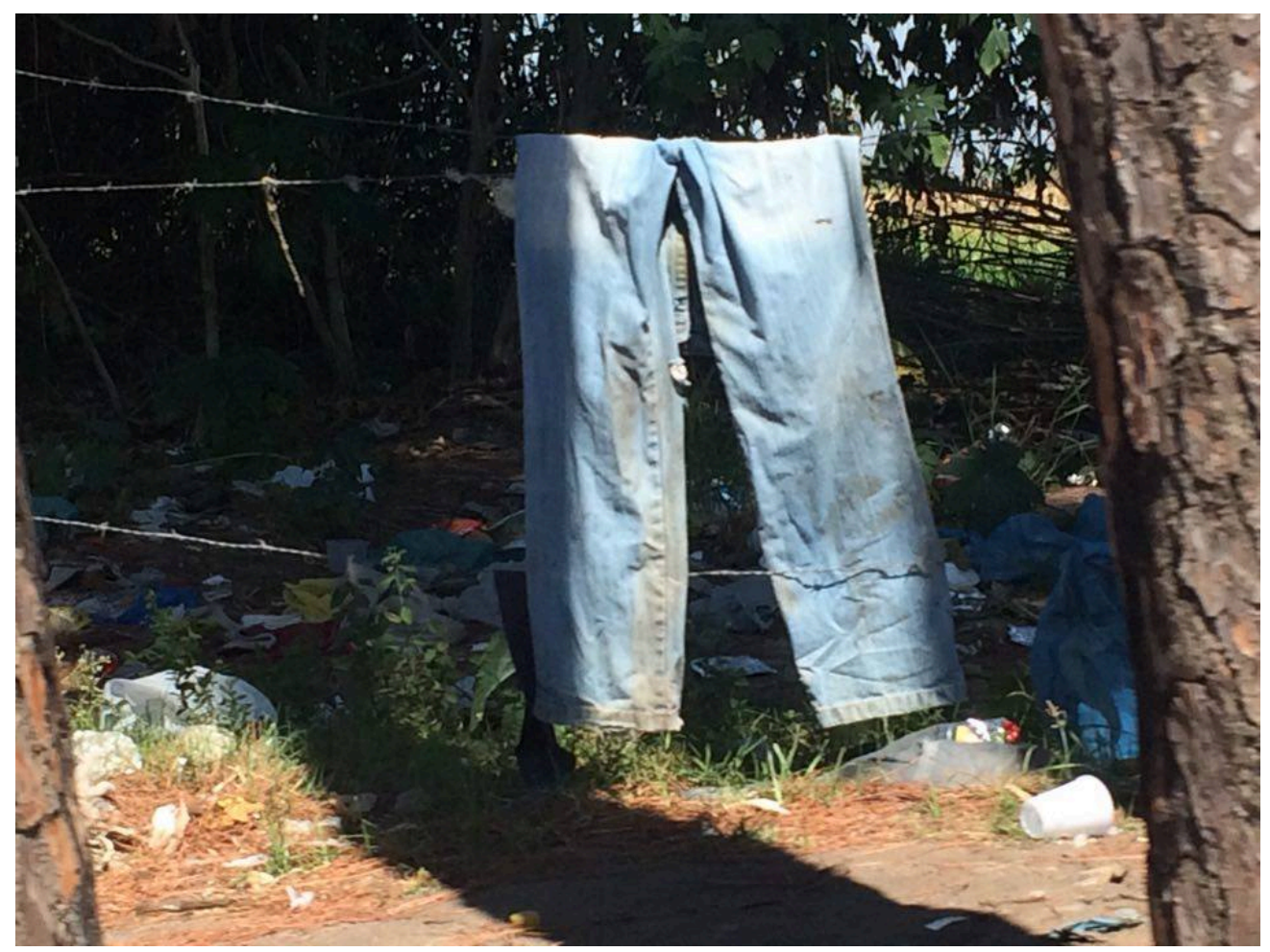

Figura 10 - Registro fotográfico do entorno do terreno do Pinheirinho. Fonte: acervo pessoal (2016).

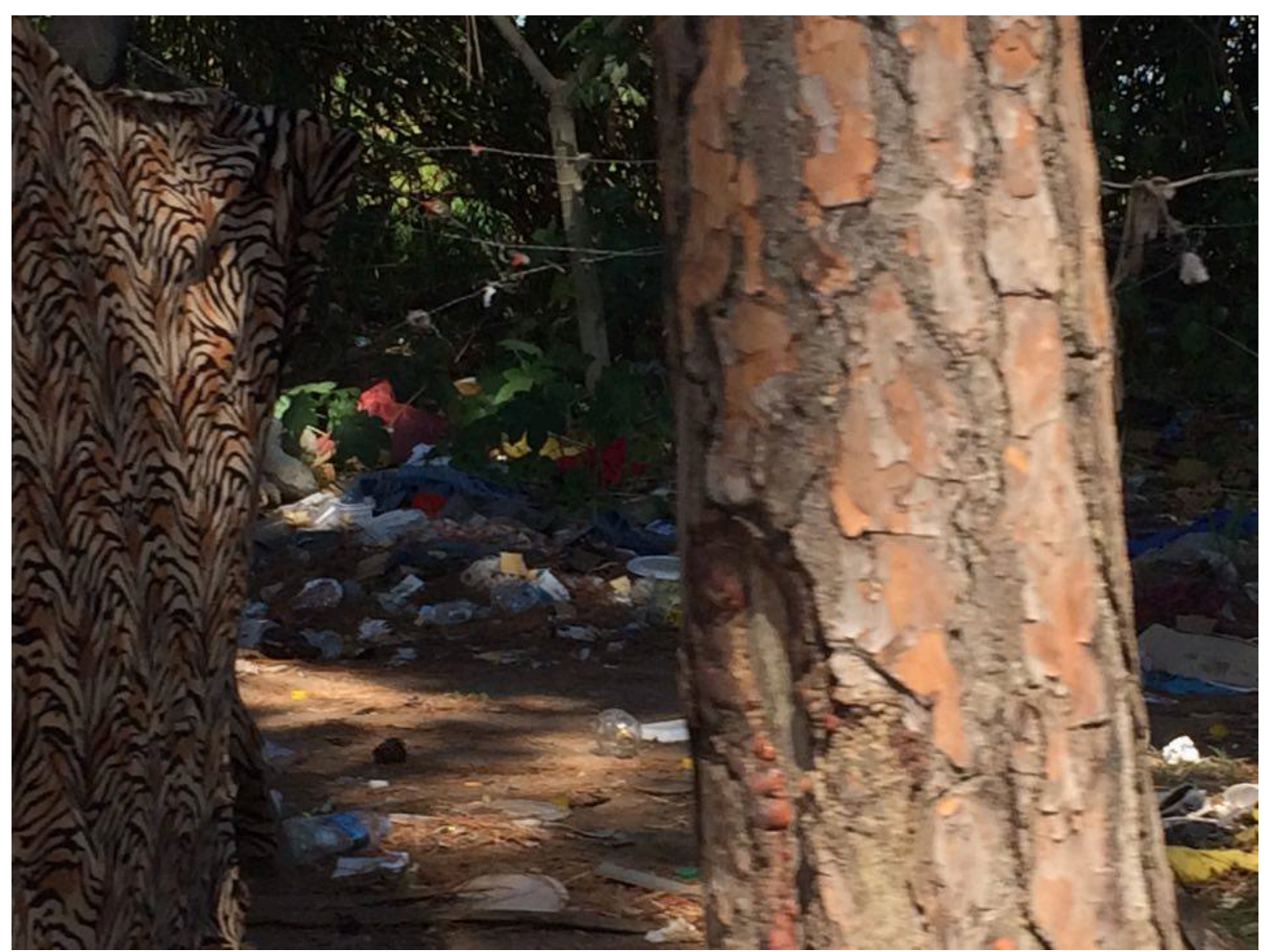

Figura 11 - Registro fotográfico do entorno do terreno do Pinheirinho. Fonte: acervo pessoal (2016). 


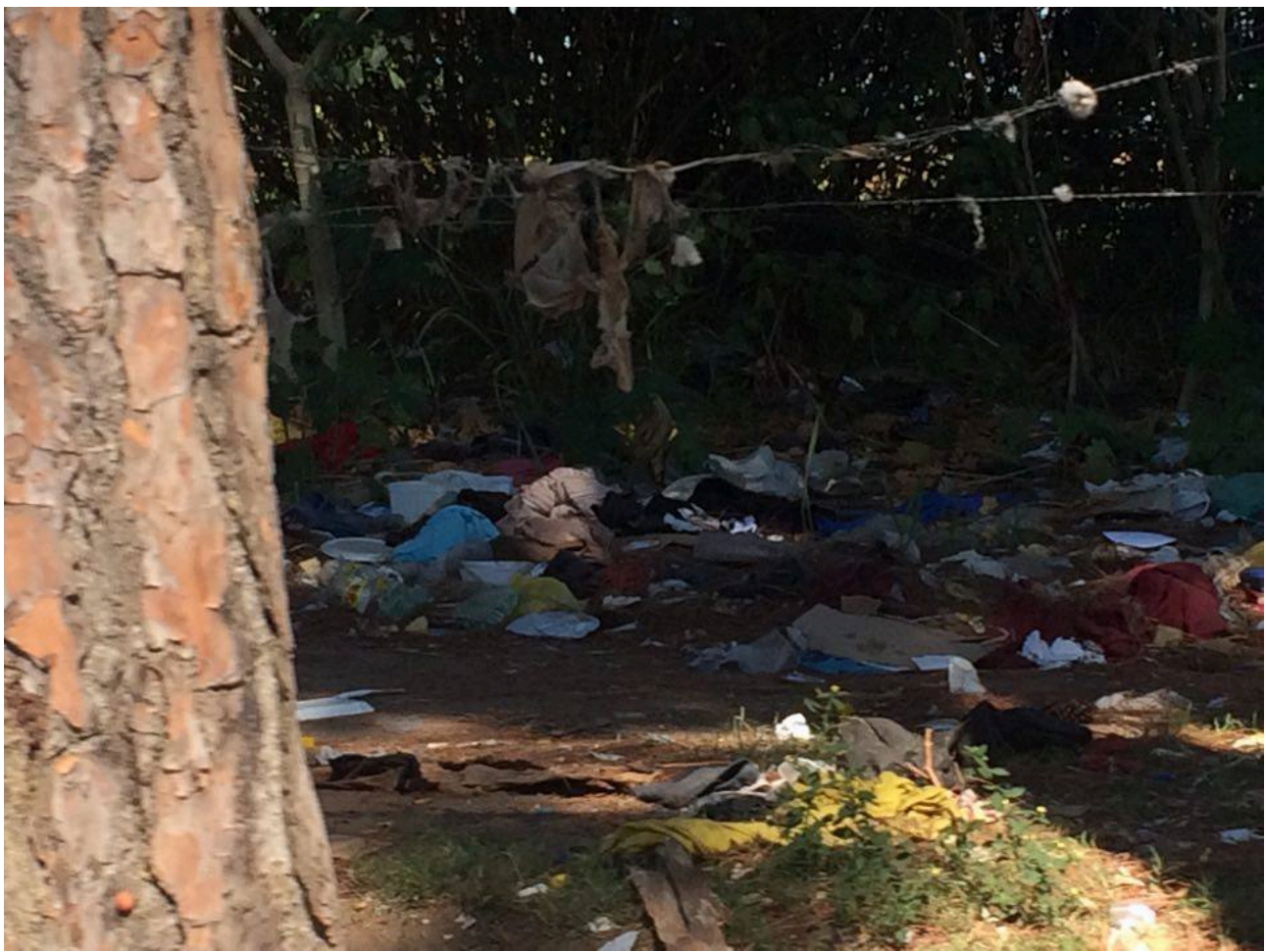

Figura 12 - Registro fotográfico do entorno do terreno do Pinheirinho. Fonte: acervo pessoal (2016).

\section{Repercussões e alternativas à violenta desocupação}

No período de ocupação do terreno, os moradores mantiveram rotina de assembleias, reuniões, manifestações e passeatas, bem como articulação frequente com outros movimentos de moradia ${ }^{13}$. Além disso, "buscaram firmar acordos com instâncias governamentais para que fosse promovida a regularização fundiária da comunidade" (Maricato, 2015), por se tratar de satisfação da necessidade de moradia sob a forma de ocupação de imóvel ocioso (Forlin \& Costa, 2010).

A possibilidade de regularização fundiária e urbanística do assentamento chegou a ser orçada em $\mathrm{R} \$ 20$ milhões, valor previsto para ser pago pelo Estado e pela União, cabendo ao município o papel de alterar o zoneamento da área para Zona Especial de Interesse Social (ZEIS) ${ }^{14}$, além de aprovar o licenciamento, visto que, segundo Souza (2016), a ocupação estava em conformidade com o Código de Obras e as demais regulações urbanísticas. Algo atestado pelo relato de Suave (2009, p. 18), ao afirmar que na ocupação "as ruas e quadras são largas. Para a divisão das casas houve uma padronização dos terrenos: cada terreno possui $250 \mathrm{~m}^{2}$ e não é permitido construir dois barracos ou casas no mesmo terreno".

Uma Ação Civil Pública ${ }^{15}$ foi ingressada pelo Ministério Público Federal (MPF) para a responsabilização do município pela omissão em "promover medidas tendentes à regularização fundiária e urbanística do assentamento precário denominado Pinheirinho, durante os anos em que a invasão do terreno privado se consolidou" (MPF, 2012b, p. 2).

Rolnik (2012a) destaca que houve uma grande falha do Poder Judiciário, que "não poderia ter emitido uma reintegração de posse sem ter procurado, junto às autoridades, verificar se as condições do direito

13 Andrade (2010, p. 134-153), sob uma perspectiva etnográfica do conflito, delineia as variadas redes de solidariedade institucionais e táticas políticas do movimento de ocupação.

14 Em virtude do litígio legal, a gleba em estudo não consta na listagem de áreas enquadradas como assentamentos precários e irregulares, identificados em 2010 no Mapa 6 - Zonas Especiais de Interesse Social, da Lei Complementar no $428 / 2010$.

15 Fundamentada no inquérito civil no 1.34.014.00001/2005-84, instaurado pelo MPF para acompanhamento da ordem judicial de reintegração de posse do imóvel ocupado pelas famílias, com apurações iniciadas em 11 de janeiro de 2005 (MPF, 2012 b). 
à moradia adequada estavam dadas". Em vista disso, é válido afirmar que o processo de remoção dos moradores do Pinheirinho violou os direitos humanos, uma vez que não pode haver remoção sem que sejam esgotadas todas as possibilidades que evitem ou minimizem o número de pessoas despejadas e desalojadas, e sem que exista uma alternativa concreta de reassentamento adequado que atenda à necessidade habitacional existente (Rolnik, 2012a).

Em decorrência da forma como se deu a desocupação, sem a oferta de alternativas ou assistência apropriada às famílias e com desrespeito ao princípio da dignidade da pessoa humana, a Defensoria Pública de SJC/SP entrou com cerca de 1.150 ações na Justiça, solicitando indenizações aos ex-moradores do Pinheirinho por danos morais e materiais. Essas ações direcionavam-se à indenização pela Selecta e pelo Estado (em função da atuação da PM na remoção), com algumas das ações incluindo o município - em virtude das precárias e insalubres condições de alojamento oferecidas após a reintegração de posse, com poucos banheiros/chuveiros disponíveis, e relatos de oferta de comida estragada às famílias (Souza, 2016).

As mencionadas ações ingressadas pela Defensoria Pública também se baseiam nas perdas ocasionadas pela remoção inesperada. Os moradores não tiveram tempo de retirar móveis, utensílios domésticos, remédios, documentos pessoais, exames médicos, como radiografias, fotos e recordações de familiares, entre outros bens particulares não recuperáveis em função da destruição das habitações (Souza, 2016) - muitas delas "invadidas, demolidas ou mesmo incendiadas [...] antes mesmo que todos pudessem ter retirado seus pertences" (Ginjo, 2016, p. 78).

Possíveis avanços, desde o episódio relatado, recaem sobre a exigência, pelo novo Código de Processo Civil (Brasil, 2015), "da presença do Ministério Público e da Defensoria Pública nas ações [de reintegração de posse], essa última quando houver população em situação de hipossuficiência econômica" (Teixeira \& Silva, 2016, p. 135).

Complementarmente, como admissível decorrência da abordagem conferida ao processo ora abordado, a problemática do déficit habitacional no município de SJC/SP se notabilizou após a desocupação do Pinheirinho, visto a criação da Secretaria de Regularização Fundiária um ano após o ocorrido $^{16}$. No entanto, a notoriedade do episódio não contribuiu para a instauração de um programa habitacional municipal próprio, sendo que a questão de moradia no município se mantém, preponderantemente, amparada por programas estaduais (CDHU) e federais (PMCMV).

\section{Ocupações urbanas e direito à cidade}

Com o modelo de desenvolvimento urbano promovendo a mercantilização da cidade em detrimento dos interesses e das necessidades da maioria da população (Saule, 2016), "a falta de oferta de moradia acessível tornou-se um dos principais problemas sociais do país, em um contexto de urbanização vertiginosamente rápida" (Rolnik, 2015, p. 267).

0 resgate dos ideais do direito à cidade torna-se pertinente, visto tratar-se de um termo já integrado ao "repertório do movimento de moradia pelo menos desde a Assembleia Nacional Constituinte" (Tavolari, 2016, p. 93), ainda que Lefebvre (2001, p. 86) tenha afirmado que "o problema da cidade ultrapassa enormemente o da moradia".

Originalmente, o direito à cidade expressava uma dimensão teórica político-filosófica, sintetizada na busca por uma nova cidade, um lugar de encontro com predominância do valor de uso. Embora tenha surgido inicialmente "a partir do diagnóstico de uma nova miséria urbana [generalizada], em que a satisfação de necessidades básicas já não aparecia como problema central" (Tavolari, 2016, p. 98), a compreensão do termo foi se transfigurando ao longo do tempo.

\footnotetext{
16 A Secretaria de Habitação do município foi criada em 2005, pela Lei Municipal no 6.808. Em 2013, a Secretaria de Regularização Fundiária foi instaurada por meio da Lei Municipal no 8.904 (PMSJC, 2016a).
} 
Com ampla aceitação no contexto brasileiro atual, o direito à cidade evoca não só a demanda por melhorias de infraestrutura, democratização na distribuição dos equipamentos coletivos ${ }^{17}$ e acesso aos espaços públicos, mas também a reflexão sobre a forma desigual de produção das cidades, em que o espaço urbano mercantilizado é parte do processo de acumulação do capital (Tavolari, 2016).

Conforme diversas leituras do conceito, a concepção mais disseminada de direito à cidade abarca, de forma abrangente, lutas isoladas e o conjunto de diversas reinvindicações urbanas coletivas, usualmente fragmentadas (Harvey, 2013, online; Tavolari, 2016). Logo, "explicitamente reconhecido como um direito coletivo" (Fernandes, 2007, p. 211), o direito à cidade atrela-se à participação popular e à função socioambiental da propriedade e da cidade.

Em uma abordagem legal do termo, Fernandes (2007) argumenta que a aprovação do Estatuto da Cidade (Brasil, 2001) significou um avanço no processo de materialização e reconhecimento formal do conceito como direito legal, e não apenas como noção política. Embora reconheça que a dimensão jurídico-institucional não tenha sido parte da proposta original de Lefebvre, Trindade (2012), na mesma linha de raciocínio proposta por Fernandes (2007), restringe a institucionalização jurídica do direito à cidade à função social da propriedade, considerando ser esse o princípio que define, justifica e legitima a existência legal do direito à cidade. Nessa acepção, tem-se o reconhecimento na Carta Magna do direito à propriedade privada atrelado à imposição de limites à sua utilização ${ }^{18}$.

Especificamente sobre o direito à moradia ${ }^{19}$, as ocupações urbanas surgem como alternativas encontradas para inserção na cidade, sendo resultado da carência de oportunidades habitacionais na cidade formal, visto a "segregação imposta pela produção do espaço urbano subordinada ao capital imobiliário" (Soraggi \& Aragão, 2016, p. 251).

Nesse sentido, é na atuação dos movimentos sociais de luta pelo direito à moradia que se evidencia a "importância das ocupações urbanas como solução habitacional e instrumento de reivindicação do direito à cidade" (Soraggi \& Aragão, 2016, p. 237). As ocupações urbanas emergem na disputa pelo espaço como formas de resistências populares contra a atual lógica mercantil de produção das cidades. As remoções, por outro lado, validam esse modelo de reprodução capitalista, com a preservação de terrenos vazios (em descumprimento à função social da propriedade) imperando sobre necessidades de moradia, e o acesso à cidade sendo negado à população de menor renda.

\section{Sobreposição do direito individual ao coletivo}

O que se constatou no caso do Pinheirinho foi a ausência de mediação que propiciasse a construção de uma solução negociada e pacífica para a situação, ocasionando na documentada desocupação violenta, que contrariou o repertório jurídico trazido pela Resolução Recomendada no 87/2009 do Conselho Nacional das Cidades (Brasil, 2009).

Diante dos frequentes despejos "realizados a partir de reintegrações de posse ordenadas pelo Poder Judiciário e executadas pela Polícia Militar, muitas vezes com uso da violência" (Rolnik, 2015, p. 278), o episódio de desocupação do Pinheirinho não se trata de caso isolado, sendo apenas uma das muitas faces assumidas pelos conflitos fundiários urbanos que reverberam a crise habitacional do país ${ }^{20}$.

17 Kowarick (2000, p. 23) utiliza a expressão contradições urbanas para se referir à desigual oferta de equipamentos e serviços públicos no território.

18 "Somente na Constituição Federal de 1988 o princípio da função social da propriedade encontrou uma fórmula consistente, que poderia ser assim resumida: o direito do imóvel urbano é assegurado, uma vez que cumpre sua função social [...]" (Fernandes, 2003, p. 65, tradução nossa).

19 "Direito humano reconhecido desde 1948 pela Declaração Universal dos Direitos Humanos e reiterado por vários tratados internacionais" (APADEP, 2014, p. 10), além de ser garantido pelo artigo 6o da Constituição Federal (Brasil, 1988).

20 Vide casos recentes, como a violenta reintegração de posse ocorrida no Hotel Aquarius, na Avenida São João, em São Paulo (em 2014); o desfecho da ocupação Terra Pelada, no Jardim Raposo Tavares, na zona oeste de São Paulo (em 2016); e o trágico desdobramento, em 2018, do incêndio no edifício Wilton Paes, localizado no Largo do Paissandu, no centro de São Paulo (ocupado por famílias organizadas pelo Movimento de Luta dos Sem Moradia). 
Reproduzindo uma situação recorrente, o direito de propriedade foi invocado, refletindo a dominante e hegemônica "visão conservadora, individualista, civilista e patrimonialista dos direitos de propriedade [...] que continua a orientar grande parte da ação dos tribunais" (Fernandes, 2008, p. 30, tradução nossa), de tal forma que um "juiz simplesmente favorece o direito à propriedade, mesmo que essa não cumpra com as suas obrigações com o Estado, como por exemplo, dívidas de IPTU" (APADEP, 2014, p. 10). Essa perspectiva ignora a necessária conciliação entre interesses individuais e sociais coletivos (Fernandes, 2003, 2005, 2008; Trindade, 2012).

Ainda que a situação jurídica da empresa proprietária do terreno impossibilitasse a desapropriação e a regularização do assentamento - visto que a municipalidade não teria jurisdição em função da existência de prioridade na resolução das pendências trabalhistas em caso de massa falida -, a forma como a desocupação ocorreu é condenável, em razão da condição de desabrigo imposto às famílias despejadas, sem a previsão de qualquer tipo de atendimento ou acolhimento provisório adequado.

Sobre a oferta de imóveis pelo PMCMV, muitas vezes tem-se a utilização de programas habitacionais como complemento aos despejos e o pagamento de aluguel social, com o valor pago a título de indenização não reconhecendo o tempo de posse, em desacordo com o que preconiza o Superior Tribunal de Justiça (Pontes, 2014). Nesse caso, houve uma aparente utilização do programa como estratégia compensatória tardia, desconsiderando-se a possibilidade de requalificação dos imóveis e manutenção da comunidade já instalada, possivelmente até por meio do instrumento "dação em pagamento" 21.

\section{Considerações finais}

Constata-se em SJC/SP uma dinâmica de valorização e mercantilização do território urbano, atrelado à industrialização da cidade, além de um cenário de defasagens no atendimento às demandas habitacionais da população carente, pelo fomento a políticas públicas que acentuaram a segregação socioespacial e não promoveram a plena inclusão urbana dos estratos de menor renda.

Salienta-se a importância de revisitar um caso emblemático que exemplifica um processo recorrente ao longo dos anos, pois, assim como em casos similares, indiferente ao fato de consolidada a ocupação em um terreno em descumprimento à função social da propriedade, com dívidas perante o poder público municipal, os interesses individuais de propriedade foram resguardados em detrimento do bem-estar da coletividade no processo de desocupação do Pinheirinho. Assim, a ocupação irregular por parte de uma população em situação de vulnerabilidade social foi tolerada por 8 anos, período em que perdurou a insegurança de posse diante da constante iminência da reintegração, com o desfecho da desocupação ocorrendo em caráter imediato.

Entre as responsabilidades negligenciadas pelo Estado, destacam-se a ausência de procedimentos para proteção social no momento de remoção - como a provisão de reassentamento digno para as famílias em situação transitória de realocação -, a inoperância em formular uma política habitacional efetiva para combate ao problema de moradia, com enfrentamento da retenção especulativa e ociosidade de imóveis públicos e privados, a indução à ocupação de vazios urbanos em áreas centrais e a priorização de destinação dos terrenos para habitação de interesse social, optando pela ineficaz política de "desfavelização".

Passados seis anos desde a reintegração de posse, verifica-se uma resolução deficiente e inacabada do conflito versado, com oferta de valores insuficientes para pagamento de aluguéis com vistas à locação de imóvel compatível; atrasos na entrega das unidades habitacionais do PMCMV; permanência da ociosidade no terreno do Pinheirinho e instalação de novos assentamentos precários nas proximidades dele (com estigmatização dos ocupantes); morosidade na execução fiscal da dívida ativa por parte da municipalidade; e periferização dos conjuntos habitacionais construídos.

\footnotetext{
21 “É uma forma de proprietários com dívidas tributárias poderem quitá-las através de terrenos ou prédios. Originalmente a dação não é um instrumento urbanístico. A dação nasceu como um instrumento tributário. Mas como implica a transferência de imóveis para o poder público, o instrumento acaba se tornando um importante instrumento para suas políticas sobretudo habitacionais" (Rolnik et al., 2009, p. 116)
} 
Como um dos principais produtores do espaço urbano, cabe ao Estado combater as iniquidades no acesso à moradia e reduzir os déficits habitacionais, algo que não pode ser atingido somente com a construção e a provisão de casas próprias, tendo em vista as diversas situações que as necessidades habitacionais requerem. Logo, seria oportuno desvincular a restritiva concepção da moradia como bem individual adquirido exclusivamente por meio do mercado privado. A complementação por meio de práticas autogestionárias de produção habitacional, propriedades coletivas, auxílio-aluguel, melhoria de unidades habitacionais, regularização fundiária e urbanização de assentamentos bem como providências para garantia da segurança de posse e de subsídios e facilidades para segmentos sociais vulneráveis são também alternativas válidas.

\section{Referências}

Alvarenga, D. N., Reschilian, P. R. (2018). Financeirização da moradia e segregação socioespacial: Minha Casa, Minha Vida em São José dos Campos, Taubaté e Jacareí/SP. Urbe. Revista Brasileira de Gestão Urbana, 13(3): 473484. http://dx.doi.org/10.1590/2175-3369.010.003.ao01.

Andrade, I. C. D. (2010). Movimento social, cotidiano e política: uma etnografia da questão identitária dos sem-teto (Dissertação de Mestrado). Departamento de Antropologia da Faculdade de Filosofia, Letras e Ciências Humanas, Universidade de São Paulo, São Paulo.

Associação Paulista de Defensores Públicos - APADEP. (2014). Moradia é um direito humano. (31a ed., pp. 9-11, Defensoria em Revista, ano VI). Recuperado em 23 outubro de 2016, de http://www.apadep.org.br/wpcontent/uploads/2016/01/Defensoria-em-Revisa-Apadep-edicao-31-junho-2014.pdf

Atlas do Desenvolvimento Humano no Brasil - ATLAS BRASIL. (2018). Perfil. Município. São José dos Campos. Recuperado em 23 junho de 2016, de http://www.atlasbrasil.org.br/2013/pt/perfil_m/sao-jose-dos-campos_sp

Brasil. (2001, 10 de julho). Lei no 10.257, de 10 de julho de 2001. Regulamenta os arts. 182 e 183 da Constituição Federal, estabelece diretrizes gerais da política urbana e dá outras providências. Brasília: Diário Oficial da União.

Brasil. (2005, 16 de junho). Lei no 11.124, de 16 de junho de 2005. Dispõe sobre o Sistema Nacional de Habitação de Interesse Social - SNHIS, cria o Fundo Nacional de Habitação de Interesse Social - FNHIS e institui o Conselho Gestor do FNHIS. Brasília: Diário Oficial da União.

Brasil. (2015, 16 de março). Lei no 13.105, de 16 de março de 2015. Código de Processo Civil. Brasília: Diário Oficial da União.

Brasil. Ministério das Cidades. Conselho das Cidades - ConCidades. (2009). Resolução Recomendada no 87 , de 8 de dezembro de 2009. Recomenda ao Ministério das Cidades instituir a Política Nacional de Prevenção e Mediação de Conflitos Fundiários Urbanos. Brasília: Diário Oficial da União, no 98, Seção 1, pág. 88.

British Broadcasting Corporation - BBC. (2016). Brazil police storm landless settlement near Sao Paulo. Recuperado em 10 de novembro de 2016, de https://www.bbc.com/news/world-latin-america-16675027

Centro de Estudos da Metrópole - CEM, Centro Brasileiro de Análise e Planejamento - Cebrap. (2013a).

Diagnóstico dos assentamentos precários nos municípios da Macrometrópole Paulista - Primeiro Relatório. São

Paulo: CEM. Recuperado em 23 junho de 2016, de http://web.fflch.usp.br/centrodametropole/upload/aaa/655-

Relatorio_I_Assentamentos_Fundap_Final_logo.pdf

Centro de Estudos da Metrópole - CEM, Centro Brasileiro de Análise e Planejamento - Cebrap. (2013b) Diagnóstico dos assentamentos precários nos municípios da Macrometrópole Paulista - Segundo Relatório. São Paulo: CEM. Recuperado em 23 junho de 2016, de http://web.fflch.usp.br/centrodametropole/upload/aaa/654Relatorio\%20II_Assentamentos_Fundap_final_logo.pdf

Crespo, J. C. V. (2013). 0 caso Pinheirinho: construções narrativas no JN e na mídia comunitária. Revista Anagrama: Revista Científica Interdisciplinar da Graduação, 6(2), 1-17. 
Empresa Paulista de Planejamento Metropolitano S/A - EMPLASA (2018). Região Metropolitana do Vale do Paraíba e Litoral Norte. São Paulo: EMPLASA. Recuperado em 23 junho de 2016, de https://www.emplasa.sp.gov.br/RMVPLN

Fernandes, E. (2003). Del Código Civil al Estatuto de la Ciudad: algunas notas sobre la trayectoria del Derecho Urbanístico en Brasil. Revista EURE - Revista De Estudios Urbano Regionales, 29(87), 63-78.

Fernandes, E. (2005). A Nova Ordem Jurídico-Urbanística no Brasil. Revista Magister de Direito Imobiliários, Registral. Urbanístico e Ambiental, 1(2), 5-26.

Fernandes, E. (2007). Constructing the 'Right To the City' in Brazil. Social \& Legal Studies, 16(2), 201-219. http://dx.doi.org/10.1177/0964663907076529.

Fernandes, E. (2008). Consideraciones generales sobre las políticas públicas de regularización de asentamientos informales en América Latina. EURE, 34(102), 25-38. http://dx.doi.org/10.4067/S0250-71612008000200002.

Forlin, L. G., \& Costa, S. M. F. (2010). Urbanização e segregação sócio-espacial na cidade de SãoJosé dos Campos-SP: o caso Pinheirinho. Geosul, 25(49), 123-158. http://dx.doi.org/10.5007/2177-5230.2010v25n49p123.

Freitas, R. N., \& Costa, S. M. F. (2005). Aplicação de técnicas de geoprocessamento na avaliação dos vazios urbanos existentes na cidade de São José dos Campos, SP, em 2000. In: Anais do XII Simpósio Brasileiro de Sensoriamento Remoto. (pp. 3763-3770.). Goiânia: SBSR.

Frota, H. B. (2015). A Função Social da Posse como Parâmetro para Tratamento dos Conflitos Fundiários Urbanos. Revista FIDES, 6(1), 37-52.

Fundação Sistema Estadual de Análise de Dados - SEADE. (2018). Perfil dos Municípios Paulistas. São José dos Campos. São José dos Campos: SEADE. Recuperado em 23 junho de 2016, de http://www.perfil.seade.gov.br/

Ginjo, M. M. (2014). Pinheirinho: um estudo de caso para pensar as interfaces do direito à moradia adequada. In Anais do XXIII Congresso Nacional CONPEDI/UFPB - A Humanização do Direito e a Horizontalização da Justiça no século XXI (pp. 354-380). João Pessoa: CONPEDI.

Ginjo, M. M. (2016). Pinheirinho: dinâmicas de repressão e resistência na reconstrução dogmática do conflito fundiário urbano (Dissertação de Mestrado). Escola de Direito de São Paulo, Fundação Getúlio Vargas, São Paulo.

Google. (2015). Google Earth. Versão 7.1.5.1557. São José dos Campos: Google. Recuperado em 19 junho 2015, de https://www.google.com/earth/.

Harvey, D. (2013). 0 direito à cidade. Revista Piauí, 82. Recuperado em 23 junho 2018 Disponível em: http://piaui.folha.uol.com.br/materia/o-direito-a-cidade/.

Instituto Brasileiro de Geografia e Estatística - IBGE. (2018). Cidades. São Paulo. São José dos Campos. Rio de Janeiro: IBGE. Recuperado 28 de junho de 2018, de

http://cidades.ibge.gov.br/xtras/perfil.php?lang=\&codmun=354990\&search=sao-paulo|sao-jose-dos-campos

Justiça Federal Seção Judiciária de São Paulo - JFSP. (2016). Consulta Processual 1o grau - SJSP e SJMS. Fóruns Federais. São Paulo: JFSP. Recuperado em 29 de novembro de 2016, de http://www.jfsp.jus.br/foruns-federais/

Kowarick, L. (2000). Escritos Urbano (1. ed.). São Paulo: Editora 34.

Lefebvre, H. (2001). O direito à cidade (5. ed.). São Paulo: Centauro.

Lespier, L. C. (Diretor) \& Beier, R. (Entrevistas e pesquisa). Keiko, N. \& Macedo, G. (Produção). Vasconcelos, V. (Diretor de fotografia e câmera 1). Santos, M. (Câmera 2). Gold, J. (Câmera 3). Gil, F. (Som direto e produção executiva). Brandão, P. \& Lima, J. M. (Produção e pesquisa). Vasconcelos, J. (Produção local). Garcia, C. (Assistente de edição). (2013). PINHEIRINHO um ano depois. [Documentário]. Abuela Produções. Recuperado de ttps://www.youtube.com/watch?v=1vzU7dJqg5Y

Macedo, F., \& Affonso, J. (2015). Governo demite delegado da Satiagraha. Estadão, Recuperado em 14 de outubro de 2015, de http://politica.estadao.com.br/blogs/fausto-macedo/governo-demite-delegado-da-satiagraha/ 
Machado, P. H. F. (2014). Pinheirinho entre o sonho e a realidade: Experiências em uma Ocupação Urbana na cidade de São José dos Campos - SP (Dissertação de Mestrado). Programa de pós-graduação em Desenvolvimento Humano: Formação, Políticas e Práticas Sociais, Universidade de Taubaté, Taubaté.

Maricato, E. (2015). Para entender a crise urbana (1. ed.). São Paulo: Expressão Popular.

Ministério Público Federal - MPF. Procuradoria da República em São Paulo. (2012a). Pinheirinho: PGR questiona decisão que manteve competência da justiça estadual. Brasília: MPF. Recuperado em 30 janeiro de 2016, de http://www.mpf.mp.br/pgr/noticias-pgr/mpf-questiona-decisao-do-stj-que-manteve-competencia-da-justicaestadual-no-caso-pinheirinho

Ministério Público Federal - MPF. Procuradoria da República no Município de São José dos Campos. (2012b). Inquérito Civil - AUTOS 1.34.014.000001/2005-84. Brasília: MPF. Recuperado em 14 janeiro de 2016, de http://www.prsp.mpf.gov.br/sala-de-imprensa/pdfs-das-noticias/SaoJose_ACP_Pinheirinho.pdf/

Montenegro, D. M. (2013). Somos todos Pinheirinho: violência, exceção e predação como interfaces da barbárie de estado. In Anais do XXIX CONGRESO ALAS CHILE: crisis e emergencias sociales en América Latina (pp. 1-9). Santiago: ALAS.

Pires, J. C. W. S., \& Souza, A. P. (2014). Operação Satiagraha: estudo de caso a partir do relatório do DPF Protógenes Queiroz. Ius Gentium, 9(5), 1-59.

Pontes, M. L. (2014). Comunidade Indiana - Programa Minha Casa Minha Vida: incentivo à política habitacional ou mecanismo de estímulo à remoção na cidade do Rio de Janeiro? In C. Muller \& K. F. M. S. Azevedo (Orgs.), Os conflitos Fundiários Urbanos no Brasil: Estratégias de Luta contra os Despejos e Empoderamento a partir da Teoria Crítica dos Direitos Humanos. (pp. 75-86.). Porto Alegre: CDES Direitos Humanos.

Prefeitura Municipal de São José dos Campos - PMSJC. Secretaria de Planejamento Urbano - SPU. (2006). Plano Diretor de Desenvolvimento Integrado - PDDI 2006 - Diagnóstico. São José dos Campos: PMSJC. Recuperado em 18 de janeiro de 2016, de https://www.sjc.sp.gov.br/media/24560/2006_pd_diagnostico.pdf

Prefeitura Municipal de São José dos Campos - PMSJC. (2011). Plano Local de Habitação de Interesse Social. São José dos Campos: Avalon Consultoria. 66 p.

Prefeitura Municipal de São José dos Campos - PMSJC (2015). Caderno Preliminar - Relatório da mobilidade urbana: diagnóstico e prognóstico. Plano Diretor de Mobilidade Urbana de São José dos Campos - PlanMob SJC. São José dos Campos: PMSJC. Recuperado em 22 setembro de 2016, de http://planmob.sjc.sp.gov.br/wpcontent/uploads/downloads/4ae068e1a0a0a49fa37f11dda9f03776.pdf

Prefeitura Municipal de São José dos Campos - PMSJC. Secretaria de Planejamento Urbano. Departamento de Planejamento Urbano. Divisão de Pesquisa (2016a). São José em dados. Informações sobre a cidade de São José dos Campos. São José dos Campos: PMSJC. Recuperado em 04 setembro de 2016, de http://www.sjc.sp.gov.br/media/667370/sjdados_2016.pdf

Prefeitura Municipal de São José dos Campos - PMSJC. Secretaria da Fazenda. Departamento de Receita (2016b). Relatório de Devedores Sintético. São José dos Campos: PMSJC.

Prefeitura Municipal de São José dos Campos - PMSJC. Secretaria da Fazenda. Departamento de Receita. (2016c). Certidão de Débitos Municipais (Imóveis). São José dos Campos: PMSJC. Recuperado em 26 de setembro de 2016, de https://www.sjc.sp.gov.br/servicos/certidao-debitos-imoveis.aspx\#sitetopo

Prefeitura Municipal de São José dos Campos - PMSJC. Secretaria de Gestão Administrativa e Finanças. Departamento da Receita. (2017). Certidão no 295179. Certidão de dados cadastrais imobiliários - Lançamento. Exercício 2017. São José dos Campos: PMSJC. Recuperado em 21 de agosto de 2017, de https://servicos.sjc.sp.gov.br/sf/acesso/cert_dados_cadastrais/certidao_impresso/2017082116381088346b7338e7-4c34-91e0-661b7c0495e6.pdf

Reani, R. T. (2016). Planejamento e zoneamento urbano: evolução do uso e ocupação do solo em São José dos Campos-SP. Revista da Associação Nacional de Pós-graduação e Pesquisa em Geografa (Anpege), 12(17), $191-218$. 
Rolnik, R. (2012a). Pinheirinho não é um caso isolado. Blog da Raquel Rolnik. Recuperado em junho de 2015, de https://raquelrolnik.wordpress.com/2012/01/27/pinheirinho-nao-e-um-caso-isolado/

Rolnik, R. (2012b). Pinheirinho: ex-moradores da comunidade estão em situação precária. É urgente que se busque uma solução definitiva. Blog da Raquel Rolnik. Recuperado em junho de 2015, de

https://raquelrolnik.wordpress.com/2012/04/19/pinheirinho-ex-moradores-da-comunidade-estao-em-situacaoprecaria-e-urgente-que-se-busque-uma-solucao-definitiva/

Rolnik, R. (2015). Guerra dos lugares: A colonização da terra e da moradia na era das finanças. São Paulo: Boitempo Editorial.

Rolnik, R., Bischof, R., Klintowitz, D., \& Reis, J. (2009). Como produzir moradia bem localizada com os recursos do Programa Minha Casa Minha Vida? Implementando os instrumentos do Estatuto da Cidade! (pp. 132). Brasília: Ministério das Cidades. Recuperado em 29 novembro de 2016, de http://polis.org.br/wpcontent/uploads/como_produzir_moradia.pdf

Rolnik, R., Klintowitz, D., Reis, J., \& Bischof, R. (2012). Pinheirinho, Cracolândia e USP: em vez de política, polícia! Blog da Raquel Rolnik. Recuperado em 23 junho de 2015, de https://raquelrolnik.wordpress.com/2012/01/23/pinheirinho-cracolandia-e-usp-em-vez-de-politica-policia/

São José dos Campos. Prefeitura Municipal. (1980, 4 de janeiro). Lei no. 2.263/80 de 04 de janeiro de 1980. Dispõe sobre o parcelamento, uso e ocupação do solo do município e dá outras providências. São José dos Campos: Diário Executivo.

São José dos Campos. Prefeitura Municipal. (1990, 25 de janeiro). Lei no . 3.721/90 de 25 de janeiro de 1990. Dispõe sobre o parcelamento, uso e ocupação do solo do município de São José dos Campos e dá outras providências. São José dos Campos: Diário Executivo.

São José dos Campos. Prefeitura Municipal. (1997, 15 de dezembro). Lei no‥ 165/97 de 15 de dezembro de 1997. Dispõe sobre a ordenação do território mediante controle do parcelamento, do uso e da ocupação do solo no Município de São José dos Campos. São José dos Campos: Diário Executivo.

São José dos Campos. Prefeitura Municipal. (2010, 9 de agosto). Lei Complementar n⿳‥428/10 de 09 de agosto de 2010 (inclusive com as alterações da LC 498/13 e LC 518/13). Estabelece as normas relativas ao parcelamento, uso e ocupação do solo em São José dos Campos, e dá outras providências. São José dos Campos: Diário Executivo.

São José dos Campos. Prefeitura Municipal. (2012, 31 de janeiro). Lei no 8598/12 de 31 de janeiro de 2012. Institui o Aluguel Social e o Auxílio-Mudança, autoriza o Poder Executivo a celebrar convênio com o Governo do Estado de São Paulo, e dá outras providências. São José dos Campos: Diário Executivo.

São Paulo. (2012, 9 de janeiro). Lei Complementar no 1.166, de 9 de janeiro de 2012. Cria a Região Metropolitana do Vale do Paraíba e Litoral Norte, e dá providências correlatas. São Paulo: Diário Executivo. Recuperado em 13 de janeiro de 2016, de

http://dobuscadireta.imprensaoficial.com.br/default.aspx?DataPublicacao=20120110\&Caderno=DOE-

I\&NumeroPagina=1

Saule, N. Jr, \& Di Sarno, D. C. L. (Coord.). (2013). Soluções alternativas para conflitos fundiários urbanos. Brasília: Ministério da Justiça, Secretaria de Reforma do Judiciário.

Saule, N. Jr. (2016). 0 direito à cidade como centro da nova agenda urbana. Boletim Regional, Urbano e Ambiental, Instituto de Pesquisa Econômica Aplicada, 15, 73-76. Recuperado em 14 outubro de 2016, de http://repositorio.ipea.gov.br/bitstream/11058/7114/1/BRU_n15_Direito.pdf

Soraggi, A. C. M., \& Aragão, T. A. (2016). 0 direito à cidade e as ocupações urbanas: um olhar sobre a Vila Eliana Silva/Belo Horizonte. In V. Marx, M. A. Costa (Org.). Participação, Conflitos e Intervenções urbanas: Contribuições à Habitat III. (Vol. 1, pp. 232-254.). Porto Alegre: UFGRS Editora.

Souza, J. S. (2016, 15 de julho). Entrevista concedida em 15 de julho de 2016, na sede da Defensoria Pública de São José dos Campos-SP. 
Suave, A. M. (2009). Ocupação do Movimento Sem Teto: limites, possibilidades e desafios da organização (Dissertação de Mestrado). Pontifícia Universidade Católica de São Paulo, São Paulo.

Suriano, A. L. C. (2013). A política habitacional e a expressão da segregação socioespacial em São José dos Campos-SP (Dissertação de Mestrado). Instituto de Pesquisa e Desenvolvimento, Universidade do Vale do Paraíba, São José dos Campos.

Tatagiba, L. (2010). Desafios da relação entre movimentos sociais e instituições políticas: 0 caso do movimento de moradia da cidade de São Paulo - Primeiras reflexões. Colombia Internacional, 71, 63-83.

http://dx.doi.org/10.7440/colombiaint71.2010.04.

Tavolari, B. M. D. (2016). Direito à cidade: uma trajetória conceitual. Novos Estudos CEBRAP (Impresso), 104, 93-109.

Teixeira, A. \& Silva, E. A. (2016). Conflitos fundiários urbanos e sistema de justiça: judicialização da política ou politização da justiça? Mediações - Revista de Ciências Sociais, 21(1), 124-144. http://dx.doi.org/10.5433/21766665.2016v21n1p124

The Guardian. (2016). Brazilian police evict Pinheirinho squatters - gallery. Recuperado em 2 de dezembro de 2016, de https://www.theguardian.com/world/gallery/2012/jan/23/brazil

Tribunal de Justiça de São Paulo - TJSP. Poder Judiciário. Portal de Serviços e-SAJ. (2017). Consulta de Processos do $1^{\circ}$ Grau. Recuperado em 17 janeiro de 2017, de

https://esaj.tjsp.jus.br/cpopg/show.do?processo.codigo=G1000AFAZ0000\&processo.foro=577\&conversationId=\& dadosConsulta.localPesquisa.cdLocal=577\&cbPesquisa=DOCPARTE\&dadosConsulta.tipoNuProcesso=UNIFICADO \&dadosConsulta.valorConsulta=44143386000166\&uuidCaptcha=\&gateway=true \&paginaConsulta=1

Trindade, T. A. (2012). Direitos e cidadania: reflexões sobre o direito à cidade. Lua Nova (Impresso), 87(87), 139165. http://dx.doi.org/10.1590/S0102-64452012000300007.

Editor: Rodrigo José Firmino.

Recebido: Ago. 03, 2017

Aprovado: Set. 17, 2018 